\title{
Establishing research strategies, methodologies and technologies to link genomics and proteomics to seagrass productivity, community metabolism, and ecosystem carbon fluxes
}

\author{
Silvia Mazzuca ${ }^{1}$ * M. Björk ${ }^{2}$, S. Beer ${ }^{3}$, P. Felisberto ${ }^{4}$, S. Gobert ${ }^{5}$, G. Procaccini ${ }^{6}$, J. Runcie ${ }^{7}$, J. Silva $^{8}$, \\ A. V. Borges ${ }^{9}$, C. Brunet ${ }^{6}$, P. Buapet $^{2}$, W. Champenois ${ }^{9}$, M. M. Costa $^{8}$, D. D'Esposito $^{6}$, M. Gullström ${ }^{2}$, \\ P. Lejeune ${ }^{10}$, G. Lepoint ${ }^{5}$, I. Olivé ${ }^{8}$, L. M. Rasmusson ${ }^{2}$, J. Richir ${ }^{5}$, M. Ruocco $^{6}$, I. A. Serra ${ }^{1}$, A. Spadafora ${ }^{1}$ and \\ Rui Santos ${ }^{*}$
}

${ }^{1}$ Department of Chemistry and Technology, University of Calabria, Rende, Italy

2 Department of Ecology, Environment and Plant Sciences, Stockholm University, Stockholm, Sweden

${ }^{3}$ Department of Plant Sciences, Tel Aviv University, Tel Aviv, Israel

${ }^{4}$ LARSyS, University of Algarve, Faro, Portugal

${ }^{5}$ Département de Biologie, Ecologie et Evolution, MARE, Université de Liège, Liège, Belgium

${ }^{6}$ Stazione Zoologica Anton Dohrn, Naples, Italy

7 School of Biological Sciences, University of Sydney, Sydney, NSW, Australia

${ }^{8}$ Marine Plant Ecology (ALGAE), Center of Marine Sciences, University of Algarve, Faro, Portugal

${ }^{9}$ Chemical Oceanography Unit, Université de Liège, Liège, Belgium

${ }^{10}$ STARESO SAS, Pointe Revellata, Calvi, France

\section{Edited by:}

Simone Cristoni, Ion Source and

Biotechnologies srl, Italy

Reviewed by:

Simone Cristoni, Ion Source and Biotechnologies srl, Italy

*Correspondence:

Silvia Mazzuca, Department of Chemistry and Technologies building

12 C, Ponte Bucci University of Calabria, 87036 Rende, Italy. e-mail: silvia.mazzuca@unical.it: Rui Santos, Marine Plant Ecology (ALGAE), Center of Marine Sciences, University of Algarve Gambelas, 8005-139 Faro, Portugal.

e-mail:rosantos@ualg.pt
A complete understanding of the mechanistic basis of marine ecosystem functioning is only possible through integrative and interdisciplinary research. This enables the prediction of change and possibly the mitigation of the consequences of anthropogenic impacts. One major aim of the European Cooperation in Science and Technology (COST) Action ES0609 "Seagrasses productivity. From genes to ecosystem management," is the calibration and synthesis of various methods and the development of innovative techniques and protocols for studying seagrass ecosystems. During 10 days, 20 researchers representing a range of disciplines (molecular biology, physiology, botany, ecology, oceanography, and underwater acoustics) gathered at The Station de Recherches Sous-marines et Océanographiques (STARESO, Corsica) to study together the nearby Posidonia oceanica meadow. STARESO is located in an oligotrophic area classified as "pristine site" where environmental disturbances caused by anthropogenic pressure are exceptionally low. The healthy P. oceanica meadow, which grows in front of the research station, colonizes the sea bottom from the surface to $37 \mathrm{~m}$ depth. During the study, genomic and proteomic approaches were integrated with ecophysiological and physical approaches with the aim of understanding changes in seagrass productivity and metabolism at different depths and along daily cycles. In this paper we report details on the approaches utilized and we forecast the potential of the data that will come from this synergistic approach not only for $P$. oceanica but for seagrasses in general.

Keywords: seagrasses, proteomics, genomics, carbon fluxes, photosynthesis, respiration, productivity, marine

\section{INTRODUCTION}

Numerous challenges can frustrate interdisciplinary research. One problem that often occurs with interdisciplinary projects is scoping the research problem. For example, it is impossible for a single person or laboratory to possess the range of skills needed to conduct truly interdisciplinary research on seagrasses. With this study, we may not have achieved many of our findings and our collective understanding would have been far less refined if we were not engaged in interdisciplinary research. Hence, researchers need to embrace collaboration with colleagues in other disciplines, such as functional genomics, proteomics, ecology, conservation, and physiology (Boudouresque et al., 2009). We anticipate that such synergies as have been outlined below will stimulate advances in other areas of seagrasses, similar to those we have been able to accomplish on Posidonia oceanica (L.) Delille. Such interdisciplinary programs are not difficult to launch because stakeholders often have shared experiences and shared concepts. However, working with colleagues who are outside of one's normal peer group can present challenges, particularly with respect to becoming fluent with the methodological basis and the scientific and technological limitations of the different specialties. A high openmindedness for different research background as well as a reciprocal 
sense of confidence and regard can be helpful. Obtaining funding for interdisciplinary research can also be challenging based on the organizational structure of granting/funding agencies as well as the institutional structure of a team that may undertake the research. For example, our team consists of academics from several institutions as well as several research agencies. In our case, the crisis of seagrasses conservation and the need for coordinated research yielded support from the Cooperation in Science and Technology (COST) Action program of the European Science Foundation with flexibility in how funds could be disbursed to different team members.

Previous work has focused on (a) how to incorporate the comparative gene expression studies with photosynthetic performance, carbon and nitrogen utilization, and environmental adaptation, and (b) how to combine the research related to mechanisms of carbon utilization, light requirements, temperature effects, and natural variation in $\mathrm{pH}$ and ocean acidification (The Royal Society, 2005; Hall-Spencer et al., 2008; Arnold et al., 2012). This work concluded that we are not yet ready to comprehensively link these disciplines because the seagrass research community is still in the nascent stages of linking eco-physiology with genomic responses. In particular, the carbon and nitrogen metabolism of seagrasses have not yet been sufficiently well-studied and the genomics has only been able to assign meaningful interpretations to a few differentially expressed genes (Procaccini et al., 2012).

Through the experimental design carried out at the Station de Recherches Sous-marine et Océanographiques (STARESO) we wished to fill these gaps and to create as links between observations at an individual and population level, and then scale up these links to the community/ecosystem level (Figure 1).

Posidonia oceanica covers about $2 \%$ of the seafloor $(25,000-$ $50,000 \mathrm{~km}^{2}$ ) in the Mediterranean Sea (Pasqualini et al., 1998). This endemic species grows to considerable depths, with meadows recorded from 0.5 to $40 \mathrm{~m}$ (Bouderesque and Meinesz, 1982), and living plants at $48 \mathrm{~m}$ depth. P. oceanica requires seawater of good quality, with low turbidity and a sedimentary budget compatible with the growth of the rhizomes and of the mat. $P$. oceanica is the most emblematic species of the Mediterranean; this robust phanerogam with long ribbon-shaped leaves grouped in clusters (shoots) is characterized by the prevalence of the asexual mode of reproduction (propagation through a dense web of plagiotropic rhizomes). In comparison with other seagrass species it is: long-lived (4-30 years) with long leaf life-span (70350 days); the rhizome biomass shows low seasonal variability, the density (number of shoots per $\mathrm{m}^{2}$ ) is relatively constant throughout the year and from year-to-year (Gobert et al., 2006), its growth rate is extremely slow, and it forms highly productive meadows (Hemminga and Duarte, 2000). The biology and the ecology of this species are well known (Bouderesque and Meinesz, 1982; Boudouresque et al., 2006; Pergent et al., 2012). In 1999, one of every four papers on the biology and ecology of all seagrass species was devoted to P. oceanica (Duarte, 1999). Mediterranean meadows have been studied more than the other species. Measurements in P. oceanica beds have been carried out at different locations of the Mediterranean Basin, but usually dealt only with seagrasses themselves analyzed at very shallow depths with different methods, at different scale. Such data can hardly be extrapolated in order to estimate the importance of any entire $P$. oceanica meadow. Since 2000 , the number of international papers on $P$. oceanica has considerably increased but there is still a paucity of papers with an interdisciplinary research focus.

What is the evolutionary potential of selected species to adapt to short and long-term environmental changes as imposed by human impacts on natural systems? The incorporation of genomic and transcriptomic techniques in the analysis of marine ecosystems and species can help us determine this (Procaccini et al., 2007; Reusch and Wood, 2007). Most of the more advanced-omics techniques have been developed in laboratory model-species, such as Arabidopsis or Oryza, but some of them are also applicable in species for which genomic resources are scarce or absent, such as most of seagrass species. In the last few years, seagrass genomic and transcriptomic resources are increasing, particularly in two species of the genus Zostera, Zostera marina, and Z. noltii, and on P. oceanica. An on line EST (Expressed Sequence Tags) database, Dr. Zompo (http://drzompo.uni-muenster.de/; Wissler et al., 2009), collects all $Z$. marina and P. oceanica ESTs available to date, but thousands of new expressed sequences are becoming available in the near future for both species, thanks to next generation sequencing approaches. The complete genome sequencing of $Z$. marina has been also performed, thanks to a JGI Community Sequencing Project - CSP 2009 (coordinator J. L. Olsen, University of Groningen, Netherlands).

Annotated EST libraries represent the starting point for a number of approaches relevant to molecular studies of ecological genetics of natural populations (Bouck and Vision, 2007). In seagrasses, recent papers address the adaptive response to environmental forcing, such as light and temperature, assessing gene expression by means of EST-related approaches. The response to temperature stress has been approached in Z. marina and $Z$. noltii through transcriptomic profiling and gene expression of target genes (Reusch et al., 2008; Bergmann et al., 2010; Franssen et al., 2011; Massa et al., 2011; Winters et al., 2011; Gu et al., 2012). Gene expression variation in response to light along a depth gradient is being examined in P. oceanica (Procaccini et al., 2010; Serra et al., 2012) while the comparative analysis of EST libraries has been performed for approaching evolutionary questions related to seagrass evolution (Wissler et al., 2011). Catalogs of expressed sequences also represent a source of putatively not-neutral markers that can be utilized for searching outliers related to environmental features. EST-linked microsatellites have been isolated both in Z. marina and P. oceanica (Oetjen and Reusch, 2007; D'Esposito et al., in press) and have been utilized, together with SNPs markers, in a genome-scan analysis on Z. marina (Oetjen et al., 2010).

Boosting genomics information in EST database makes, from now, proteomic analyses more attractive for P. oceanica than in the past, because protein sequence analysis and identification are less challenging.

Proteomics is a promising powerful tool to compare quantitative/qualitative differences in thousands of proteins in P. oceanica from meadows living in different environments. Hence, by identifying the expression of different proteins under various conditions, we might validate these proteins as early biomarkers for ecophysiology assessment. On the other hand, the various metabolic 

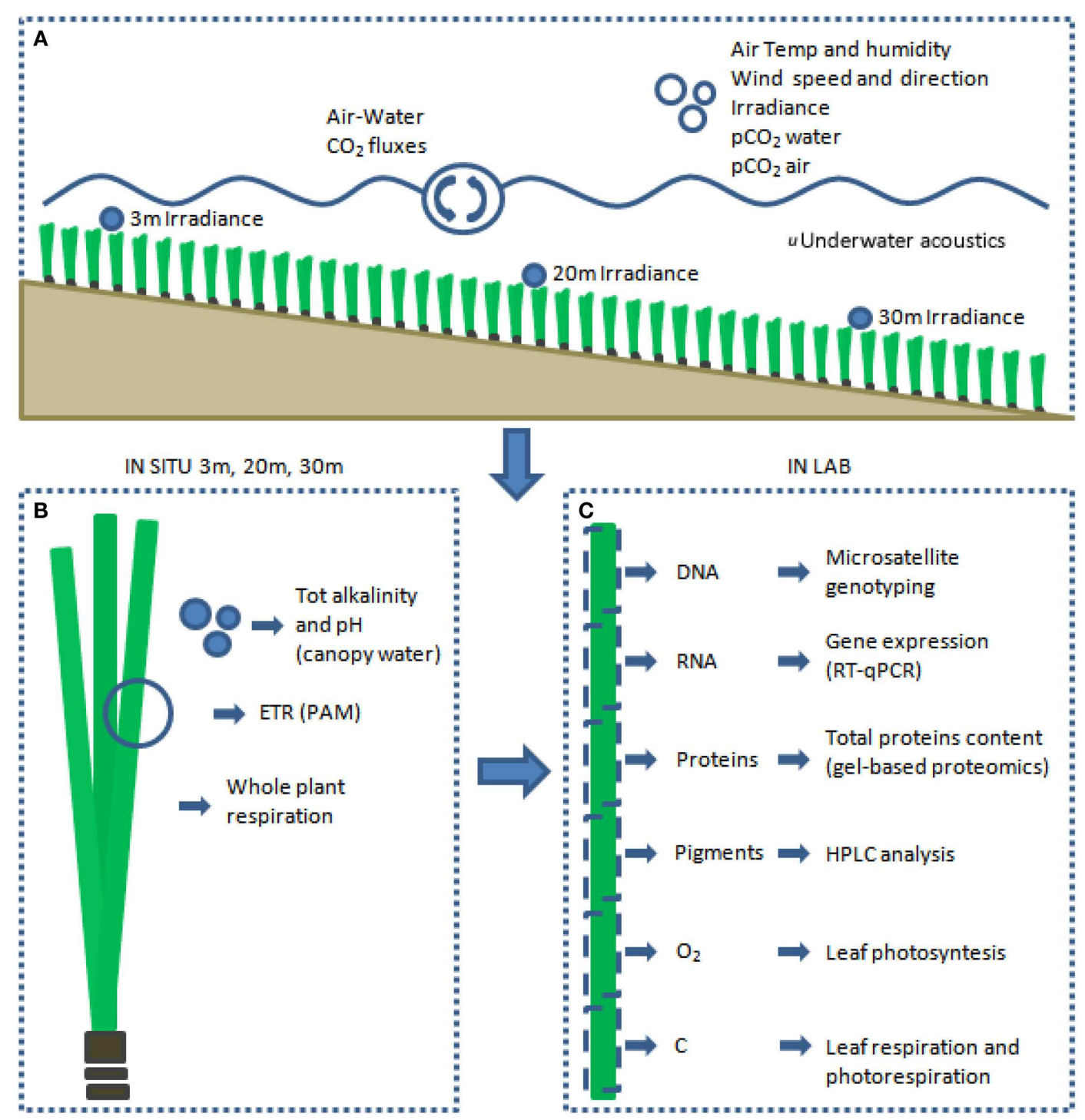

FIGURE 1 | Summary of methodological approaches performed in situ at community level (A) and at plant level (B). Replicate shoots were collected for each depth for physiological and molecular analyses that were performed all on the same leaf (C)

pathways which are utilized under different conditions could represent a starting point to clarify how $P$. oceanica is able to adapt. To express its full potential, proteomics must rely on samples of high protein quality. Consequently, the newer methods of extraction, separation, and analysis of the entire proteome from a specific tissue, or from organelles that are now evolving in many plants, must also be implemented for seagrasses at local and large scales. The protein expression approach and the bottom-up experimental design together with the high-throughput technologies for mass spectrometry promise a large amount of empirical information on the seagrass proteome in the coming years. This large amount of information should be added to relevant seagrass databases in order to facilitate the organization of data to generate testable hypothesis. The application of new technique(s) combining twoor one-dimensional (1D) SDS-PAGE with a high-mass-accuracy
LC-ESI-MS and LC-SACI-MS and MS/MS to sequence identification approaches has demonstrated an increase in the confidence of results (Finiguerra et al., 2010). This can provide a highthroughput system to achieve the goal of sequencing complete proteomes from seagrass organs and tissues. By databases such as EST, Transcriptomics, and Genomics, the genomic data from seagrasses can be interrelated with the emerging protein sequences and metabolic data as well as with environmental information.

How are seagrasses able to biochemically survive a marine life style? Since the proteome of each living cell is dynamic, proteomics allows investigators to clarify if, and to what extent, various pathways are utilized under varying conditions and triggered by the action of the environment on the system, and the relative protein level response times. Previously, two-dimensional gel-based proteomic studies on Posidonia meadows acclimated to different 
light conditions revealed physiological pathways involved in the acclimation of seagrasses to low-light, evidenced by Rubisco downregulation; in contrast, enzymes involved in carbohydrate cleavage (1-fructose-bisphosphate aldolase, nucleoside diphosphate kinase, and beta-amylase) were up-regulated (Mazzuca et al., 2009). Afterward, the 1D gel-based proteomics and label-free approach applied to shaded adult leaf tissues showed significant down-regulation of the isoforms of $\beta$-carbonic anhydrase (Serra and Mazzuca, 2011). This kind of high-throughput proteomics revealed also that about $40 \%$ of the differentially expressed proteins in lowlight appeared to be involved in chloroplast metabolic pathways (Dattolo et al., submitted). The "sub-organelle proteomics" strategy from the three different compartments - envelope, stroma, and thylakoids (Ferro et al., 2010) - is now being applied to $P$. oceanica (Mazzuca, personal communication).

Genetics can provide the bases for the plant physiological response to different environmental forcing, because it can be more or less plastic at either individual, population or species level. Precise knowledge of population genotypic composition and population genetic isolation/connectivity with distinct populations can help in interpreting functional responses and in framing the results of functional studies. In order to do this, we used species-specific microsatellite markers to genotype a standard representative number of individuals collected at 5 and $20 \mathrm{~m}$ depth. On the same individuals, newly selected EST-linked microsatellite were also scored, in order to look for outlier loci, that could be linked to specific environmental variables.

The study has been conducted both at the community level and plant level. At the community level we aimed to estimate the net community production (NCP) and the community respiration (CR) of $P$. oceanica using incubation chambers and monitoring the evolution of $\mathrm{O}_{2}$ production and consumption, respectively. At plant level we aimed to understand the primary metabolic pathways involved in the carbon budget, from the expression of selected genes, to the expression of proteins, to the assessment of photosynthetic and respiratory performance. Key genes have been selected along the whole photosynthetic and respiratory pathway and their expression has been evaluated by RT-qPCR along daily cycles at different depths. The photosynthetic pathway includes genes showing positive selection in respect to terrestrial plants (Wissler et al., 2011), and is worth investigation. We used an RNASeq approach used to detect differentially expressed genes between depths and plant portions (leaves and roots). On the side of proteins we applied the 1D label-free approach coupled with a spectral counting strategy to look at the overall expressed proteins (Schulze and Usadel, 2010). Although we expected the overall pattern of protein expression to be similar to that of mRNA expression, the incongruent expression between mRNAs and proteins can occur, emphasizing the importance of posttranscriptional regulatory mechanisms in cellular development, or perturbations that can be unveiled only through integrated analyses of both proteins and mRNAs. Thanks to the quantitative proteomic techniques (1D electrophoresis and mass spectrometry), we evaluated the correlation of each selected mRNA at corresponding protein level. The aim has been to capture a meaningful variation of selected protein expression (up and down) that can overlap with the differential expression of mRNA (up or down).
Since photosynthesis is the basis for plant growth, it follows that there should be a correlation between photosynthesis and growth. There should be a positive correlation between the rate of photosynthesis during the daytime corrected for that of respiration dielly (during the day and the night) and growth rate. As long as this balance is positive, i.e., daily photosynthesis exceeds diel respiration, the plants should grow if not constrained by other, non-photosynthetic or non-respirational, influences (such as grazing or uprooting or the like). This correlation between photosynthesis + respiration and growth is easy to show for simply built plants such as micro- and macro-algae (e.g., Lipkin et al., 1986), but is much harder to quantify for higher plants such as angiosperms. In seagrasses, which like their terrestrial-plant counterparts have both above- and below-ground tissues, it is relatively easy to measure rates of photosynthesis and respiration of the leaves, but much harder to measure rates of respiration of the underground roots and rhizomes, and especially so when in situ rates are sought. Therefore, till now, rates of photosynthesis have been used as a general indicator of the growth status of seagrasses, but respiration has largely been ignored. In this study we incorporate this important factor when measuring whole-plant or plantcommunity-based metabolism as a proxy for seagrass growth.

Photosynthesis and respiration measurements have traditionally been based on either $\mathrm{O}_{2}$ or $\mathrm{CO}_{2}$ exchange. In the aquatic environment, $\mathrm{O}_{2}$ measurements are far easier to perform than those of $\mathrm{CO}_{2}$ exchange. The big advantage in using such gas exchange measurements as a proxy for plant growth is that results can be obtained quickly (minutes to hours, rather than days to weeks for growth measurements). During the past 10 years, an even quicker method has been developed for photosynthetic measurements with a resolution time of seconds to minutes: pulseamplitude modulated (PAM) fluorometry. This method measures quantum yields (Y) as photosynthetic electron transport per photon absorbed by the photosynthetic pigments. When multiplying $\mathrm{Y}$ with the photosynthetic active radiation (PAR) absorbed by the photosynthetic pigments of photosystem II (PSII), then photosynthetic electron transport rates (ETR) can be calculated in mol electrons $\mathrm{m}^{-2}$ leaf surface $\mathrm{s}^{-1}$. It should also be noted that parameters indicating stress, as well as considerations of the mechanisms involved in photosynthesis and other non-photosynthetic processes (e.g., photosynthetic and non-photosynthetic quenching), can also be elucidated by PAM fluorometry. While the quantitative accuracy of this method has been verified for several (e.g., Beer et al., 1998), and especially thin-leaved (Beer and Björk, 2000) seagrasses, its main drawback is that it ignores respiration and, thus, only photosynthetic rates per se can be measured. In order to obtain time series of these photosynthetic measurements, modulated fluorometers have been developed that can measure photosynthetic parameters in situ continuously for several days (Runcie et al., 2009; Runcie and Riddle, 2012).

In recognizing that respiration must be included in metabolic measurements that lead to information regarding growth rates, we are now trying to incorporate such measurements, either in situ or in the laboratory while mimicking in situ conditions. Thus, the present consortium will complement other groups by providing diurnal data not only on photosynthetic rates, but on gas exchange in general and respiration in particular. 
Finally, unlike in situ methods, which only provide local measurements of photosynthesis related parameters, acoustic based methods can potentially allow the instantaneous quantification of oxygen production at meadow level, giving an integral estimate of $\mathrm{O}_{2}$ concentration along the propagation paths of the acoustic signal. In general, acoustic signals propagating through the ocean are sensitive to gas bubbles (Wilson, 1988; Medwin and Clay, 1998). In previous experiments (Hermand and Alberotanza, 2000; Hermand, 2003), it was shown that signatures in acoustic signals transmitted through $P$. oceanica meadows were highly correlated with the photosynthetic rate, which was ascribed to produced bubbles and gas filled aerenchyma. Wilson et al. (2012) observed a similar correlation in an experiment conducted in a Syringodium filiforme meadow, but in this case at a plant shoot scale. The acoustic system, as a low cost remote sensing tool to assess the photosynthetic activity of the P. oceanica meadow was here used in real time, although a fully operational system requires further investigation in methods for system calibration.

Here, as first step for calibration we also used a mooring at $10 \mathrm{~m}$ with an array of three optodes for oxygen measurements at hourly intervals. The temporal changes at daily scale of water column inventory of $\mathrm{O}_{2}$ allows the quantification of GPP and CR based on the Odum (1956) method. This approach was used successfully at STARESO (Champenois and Borges, 2012).

\section{METHODS AND STRATEGIES HOW IMPORTANT IS THE LOCATION IN OUR APPROACH}

In the framework of marine interdisciplinary research, the site where field experiments are matched with lab activities is central. STARESO $\left(8^{\circ} 45^{\prime} \mathrm{E}, 42^{\circ} 35^{\prime} \mathrm{N}\right)$ belongs to the University of Liège (Belgium) and acts also as a Technical Office toward communities and private customers in the field of marine environmental impact studies. STARESO is located in the Calvi Bay on the northwest coast of Corsica in the Mediterranean Sea. This oligotrophic area is classified as a "pristine site" where environmental disturbances caused by anthropogenic pressure are exceptionally low. The study site includes representatives of most major coastal ecosystems of the Mediterranean. The Calvi Bay is characterized by healthy benthic and pelagic ecosystems associated with a high biodiversity close the Liguro-Provençal current (Figure 2). The marine lab offers direct access to the sea, and facilitates investigations using diving, boats, and laboratories. Since 1970, time series of physical, chemical, and biological data (sampling at sea with automated systems and sensors deployed in the Bay, as well as in situ experiments) have been recorded. In front of the lab, P. oceanica (L.) Delile is the dominant ecosystem going from the surface to a lower limit that reaches $37 \mathrm{~m}$.

A large collection of data focused on P. oceanica ecosystem diversity and functioning has been collected over the last 40 years. As a result, the seasonal and inter-annual dynamics of the major primary producers relating to the ambient parameters (temperature, winds, nutrient concentrations) are well known in the site (Bay, 1984; Lepoint et al., 2002; Gobert et al., 2003a). In spite of the very low nutrient concentrations, the meadow displays high biomass and productivity (more than $500 \mathrm{gdw} \mathrm{m}^{-2} \mathrm{y}^{-1}$ ) and is considered to be a Low Nutrient-High Chlorophyll (LNHC) system (Gobert et al., 2002). The meadow is healthy (Gobert et al., 2009) and no significant changes of the vitality have been registered since 1975. Long-term follow-up show only classical interannual and seasonal variations of biomass and production that relate with ambient factors (temperature, winds, light) (Bay, 1984; Gobert et al., 2003b). However, an increase of the flowering frequency has been observed since 1975 , and this may be related to the general increase of the temperature in the Mediterranean Sea (Gobert et al., 2001). Furthermore, local evidence of mechanical damage due to the anchoring of recreational boating has been recently detected.

The direct proximity of underwater in situ field analysis and the wet and dry lab allowed very easy sampling of biological material and fast processing of tissues for molecular analysis. Quality of the results due to this proximity is can be enhanced with continuous installation of different kind of in situ probes directly connected to the lab (e.g., salinity, temperature, weather station).

Finally, in the same way as an oceanographic ship, the marine lab offers full logistic capabilities (meeting rooms, efficient internet connection, meals, and lodging accommodations) that enabled scientific work day and night without interruption. As a consequence, one has confidence in results derived from the study, in particular those obtained through integration and interpretation of data from the different scientific disciplines.

\section{WHAT TIMING, WHAT METHODOLOGIES AND TECHNOLOGIES FOR COOPERATIVE SAMPLES COLLECTION, IN SITU DEPLOYMENT OF EOUIPMENT, DATA COLLECTION, AND ANALYSIS}

As pointed out above, there are several ways to estimate the metabolic processes of seagrasses, each having its advantages, but measuring with different approaches. In order to compare such data, sampled with different methods, it is important to perform simultaneous field methods calibrations. We selected the meadow along a deep gradient and fixed daytimes corresponding to supersaturating and limiting irradiances as extreme conditions. Between these, many intermediate times were considered. Timing between the underwater in situ field analyses, the sampling of biological material and the processing of tissue for molecular analyses, which is typically done by fixing tissues in suitable buffers or by freezing them in liquid nitrogen, is the real challenge; the shorter the time between these events, the greater the confidence in the results from different specialties. To achieve this goal the sampling design has been careful planned in terms of the number of operators, suitable devices, and tools, time needed to carry each sample from the sea to the lab (Table 1).

Therefore, in this activity we set out to compare.

(i) How photosynthetic rates obtained by using modulated fluorometry may correlate with gas exchange measurements at both the plant and the community levels $\left(\mathrm{O}_{2}\right.$ electrodes in the lab and community metabolism as well as modulated fluorometry in situ.

(ii) How continuous measurements with the autonomous modulated fluorometers correlate with the discrete measurements obtained with the conventional Diving-PAM.

(iii) How circadian changes in acoustic signal correlates with gas exchange measurements at the community levels. 

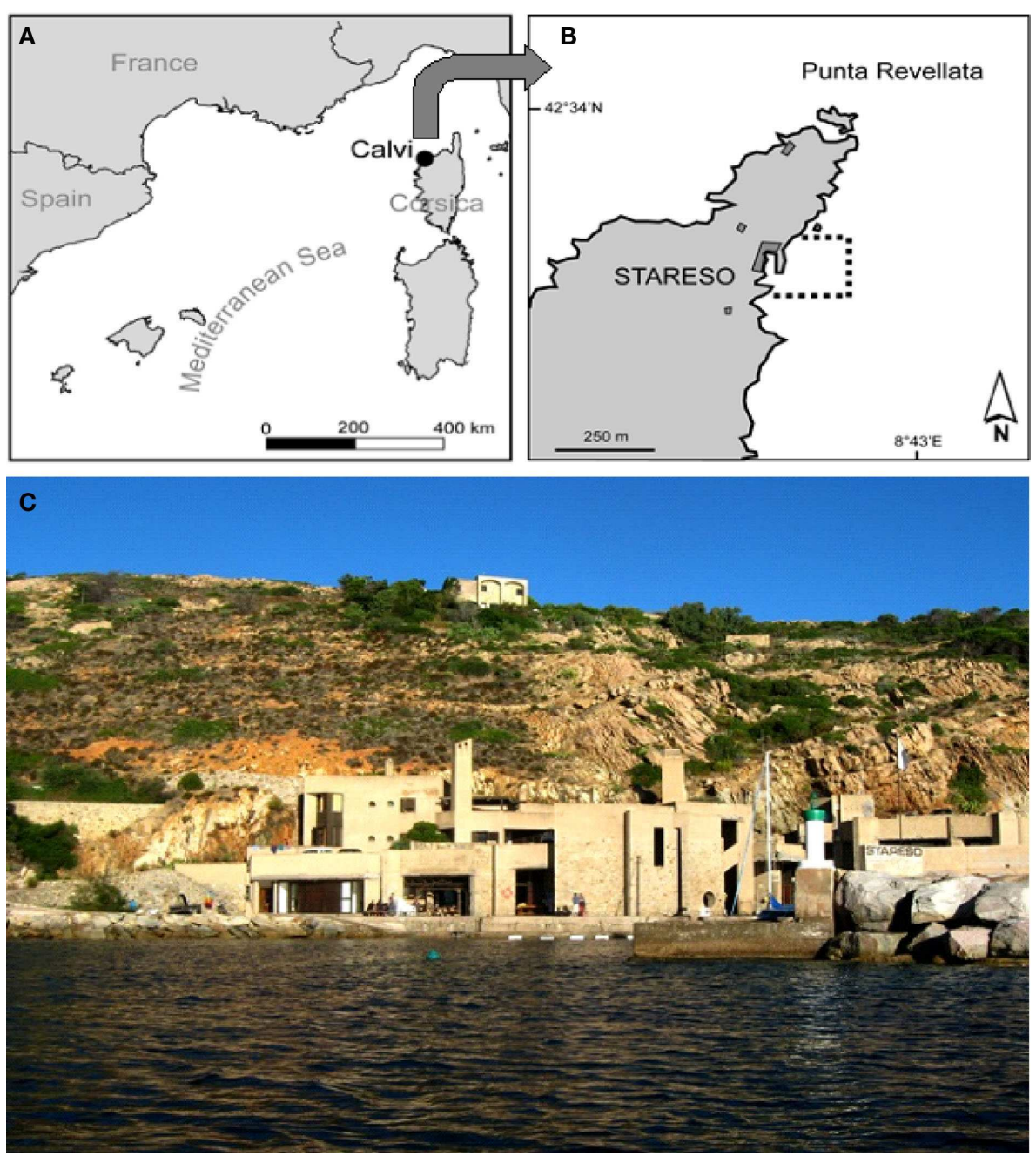

FIGURE 2 | Location of the study area in (A, B) the Calvi Bay, North Westerrn coats of Corsica, Mediterranean Sea, at the latitude and longitude of $8^{\circ} \mathbf{4 5 0 E}, \mathbf{4 2}^{\circ} \mathbf{3 5 0 N}$. (C) The Station de Recherches Sous-marines et Océanographiques, STARESO.

(iv) How to catch the photosynthetic regulation change in relation to light intensity (shallow site and deeper site) during the day.

To address these questions, submersible modulated fluorometers (Shutter Fluorometer and Classic Fluorometer, Aquation Pty Ltd., Australia, (Figure 3) were deployed for $\sim 24 \mathrm{~h}$ at 5,20 and $30 \mathrm{~m}$ depth in the afternoon of the 16th October 2011. Seagrass leaves were positioned in the sample holders of the fluorometers so that a portion of leaf halfway along the blade was examined. Epiphytic material was gently removed by rubbing. After $\sim 24 \mathrm{~h}$, new leaves were positioned in the sample holders and a further $\sim 24 \mathrm{~h}$ measurement was conducted. Leaves were oriented horizontally. Irradiance was measured both nearby with a dedicated light logger, and using the PAR sensor that is part of the shutter fluorometer.

At $5 \mathrm{~m}$ depth, a total of four leaves were measured over the 2 day period. At $20 \mathrm{~m}$ depth, two individual leaves were measured, and at $30 \mathrm{~m}$ depth three leaves were measured each day, making a total of six leaves over the 2 day interval. Leaves were collected from 5 and $30 \mathrm{~m}$ depth and absorptance of these leaves was measured using a Diving-PAM light sensor calibrated against a LiCOR 193SA PAR sensor (Beer and Björk, 2000).

One shutter fluorometer each at 5 and $20 \mathrm{~m}$ depth were programed to perform rapid light curves (RLCs) on samples at 06:00, 9:00, 12:00, 15:00, and 18:30 h. All fluorometers, including those programed to conduct RLCs, conducted effective quantum yield measurements every $15 \mathrm{~min}$. In addition, every second measurement was followed by $10 \mathrm{~s}$ of exposure to far red light (FRL) with ambient light excluded using the shutter; this was followed by another saturating pulse measurement. From the measurement immediately following the FRL we determined Fo', and used this value to calculate components of non-photochemical quenching (Runcie et al., 2009). Effective quantum yield measurements (excluding those immediately after exposure to FRL, or those 


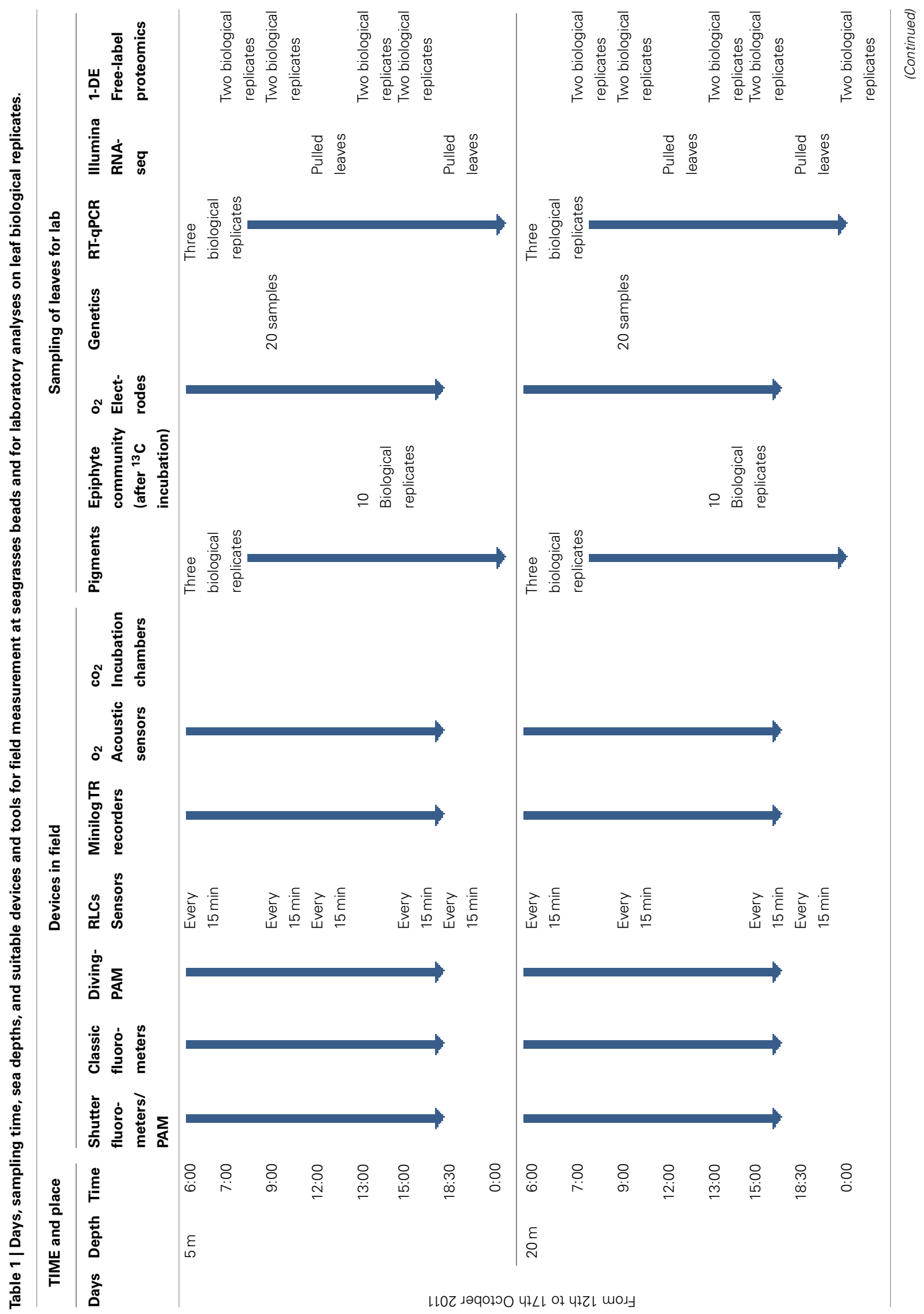




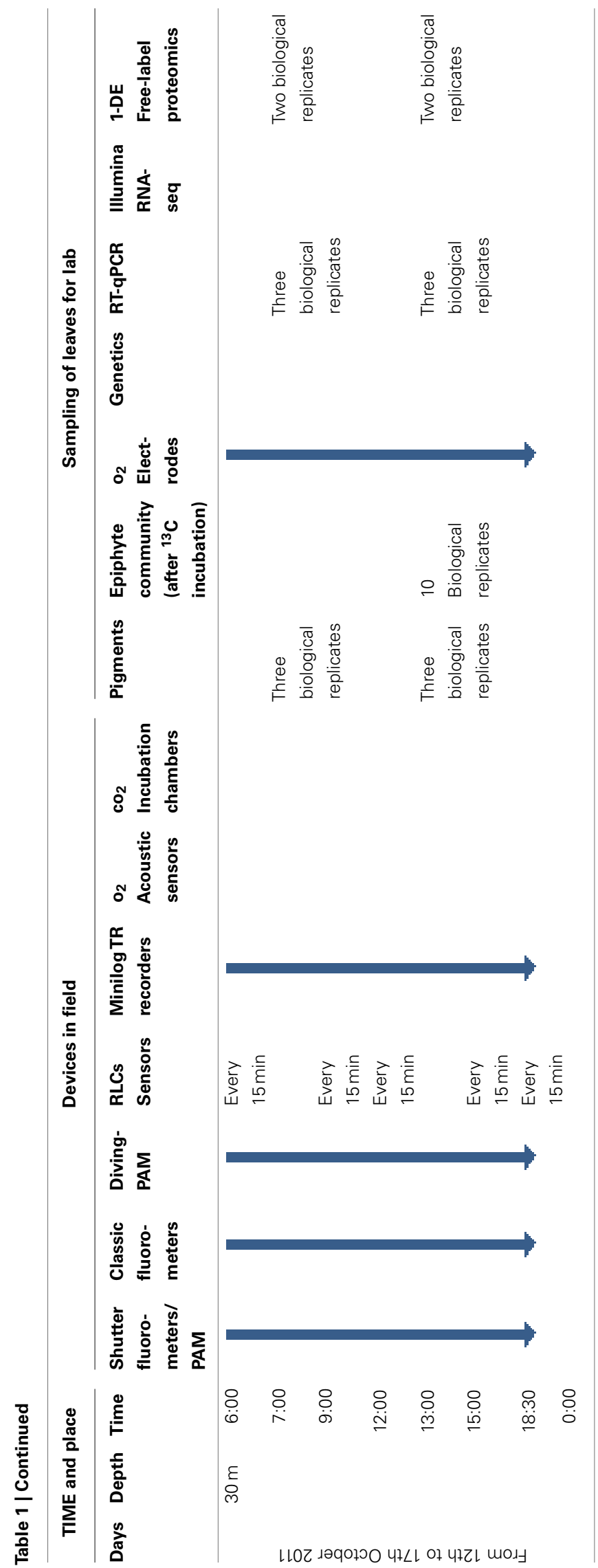

obtained during a RLC) were used to calculate ETR, and diel PE curves were constructed by comparing ETR with ambient irradiance measured at the time of measurement. For these calculations we used absorptance values as obtained from leaves at 5 and $30 \mathrm{~m} ; 20 \mathrm{~m}$ samples were assumed to be similar to those at $30 \mathrm{~m}$ (see Runcie et al., 2009). The value 0.5 was used, assuming equal sharing of exciton energy between Photosystems I and II. RLCs and diel PE curve data were described using models of Platt et al. (1980) with a term for photoinhibition or Webb et al. (1974) (two parameter model with no term for photoinhibition); non-linear least squares minimization techniques using the Levenberg-Marquardt algorithm were employed using the Optimiz software. Diel PE data were pooled for all leaves measured over the 2-day interval at each depth, and a single model fit to this data. Error values for Ek estimates were calculated by propagation of errors. Data are reported with means and standard errors. Non-photochemical quenching components were calculated as described in Runcie et al. (2009).

(v) How do long incubation times affect estimates of community metabolism?

The effects of the duration of incubation on the estimations of community metabolic rates have been tested here for the first time. The rationale to test this is that the deployment of the incubation chambers over a dense seagrass meadow results both in the accumulation of $\mathrm{O}_{2}$ within the chambers and an increase in $\mathrm{pH}$ due to the photosynthetic consumption of $\mathrm{CO}_{2}$. At high $\mathrm{O}_{2}$ and low $\mathrm{CO}_{2}$ levels, the enzyme Ribulose-1,5-bisphosphate-carboxylase oxygenase switches from carboxylase to oxygenase activity (Heber et al., 1995). Under these conditions, there is consumption of $\mathrm{O}_{2}$ and release of $\mathrm{CO}_{2}$ by photorespiration, which will result in the underestimation of GPP. On the other hand, the $\mathrm{CO}_{2}$ photosynthetic consumption by seagrasses in closed environments may drive the $\mathrm{pH}$ to values up to 9.2 (Beer et al., 2006), causing a linear decrease of the photosynthetic rates (Invers et al., 1997). The availability of dissolved $\mathrm{CO}_{2}$ at high $\mathrm{pH}$ levels is residual and thus the photosynthetic production is only possible if producers are able to utilize the very abundant $\mathrm{HCO}_{3}{ }^{-}$form of inorganic carbon. Even though many marine macrophytes, including seagrasses, have been found to be able to utilize $\mathrm{HCO}_{3}{ }^{-}$as an external source of inorganic carbon for their photosynthetic needs (Beer et al., 1998), the rate of $\mathrm{CO}_{2}$ consumption will be lower and thus the GPP will be underestimated.

(vi) How to evaluate the contribution of epiphytic communities on the P. oceanica leaves to the overall C-flux?

The parallel use of two techniques has been implemented to evaluate the contribution of epiphytes living on $P$. oceanica leaves to NCP: " ${ }^{13} \mathrm{C}$ tracer incorporation" and "Biomass accumulation." ${ }^{13} \mathrm{C}$ tracer experiments were carried out in the enclosures used for $\mathrm{NCP}$ measurements. A ${ }^{13} \mathrm{C}$ labeled $\mathrm{Na}_{2} \mathrm{CO}_{3}$ solution $\left(99.0 \%{ }^{13} \mathrm{C}\right)$ (Eurisotop, France) was added to each incubation plastic bag with a syringe. The solution was acidified underwater just before the injection to produce dissolved $\mathrm{CO}_{2}$ and $\mathrm{HCO}_{3}{ }^{-}$. 

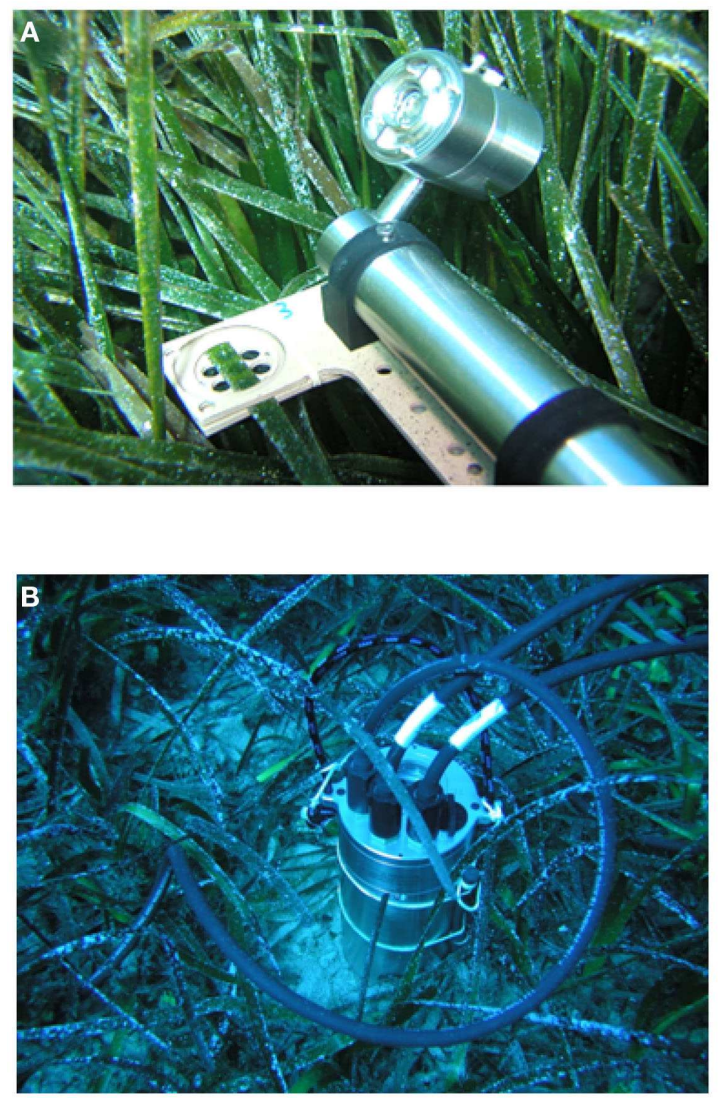

C

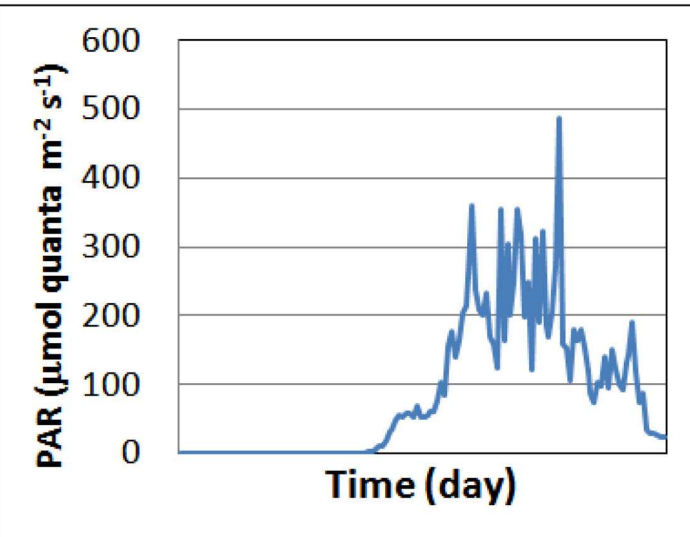

D

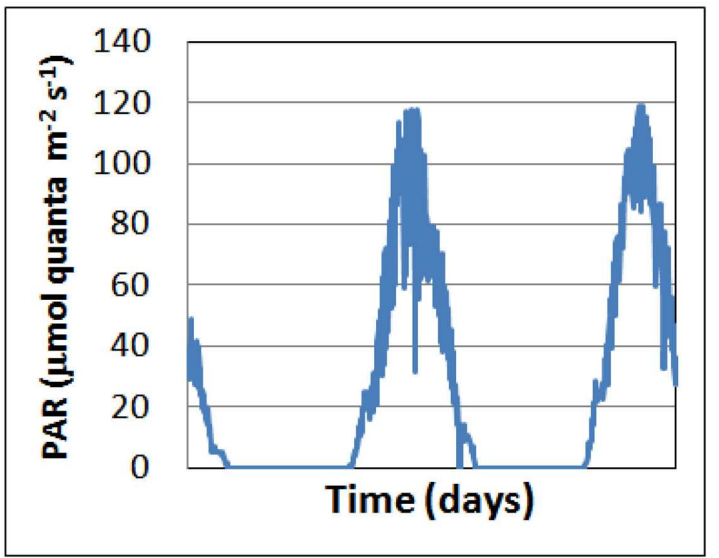

FIGURE 3 | Submersible modulated Shutter Fluorometer (A) and Submersible Datalogger (B), Aquation Pty Ltd, Australia and detected daily PAR measurements in shallow (C) and deep (D) plants.

After incubation, P. oceanica shoots were uprooted; control plants were also collected. Isotopic and elemental measurements were performed with an isotopic ratio mass spectrometer (Isoprime 100, Isoprime, United-Kingdom) coupled to a $\mathrm{C}-\mathrm{N}-\mathrm{S}$ elemental analyzer (Vario Micro, Elementar, Germany). The abundance of ${ }^{13} \mathrm{C}$ in $P$. oceanica leaves and in epiphytes was expressed in atom $13 \mathrm{C} \%$, i.e., the proportion of ${ }^{13} \mathrm{C}$ atoms relative to the total $\mathrm{C}$ atoms $\left({ }^{12} \mathrm{C}+{ }^{13} \mathrm{C}\right)$. Two units are used to express the elemental composition: the $\mathrm{C}$ content which is expressed in $\mathrm{mg} \mathrm{C}$ shoot $^{-1}$ (in leaves and in epiphytes) and the $\mathrm{C}$ relative concentration which is expressed in percent relative to the total dry weight ( $\% \mathrm{dw})$. We have adopted a very conservative approach to calculate the ${ }^{13} \mathrm{C}$ in excess in the labeled P. oceanica and epiphyte. Classically, the natural ${ }^{13} \mathrm{C}$ abundances in samples were subtracted from the measured ${ }^{13} \mathrm{C}$ abundance in control plants. But, natural ${ }^{13} \mathrm{C}$ abundance for epiphytes and leaves were set to average values measured on control shoots plus three times the standard deviation around this average in order to minimize the risk to confound labeling effect and natural isotopic variability. Therefore, calculated enrichments as low as $+0.001{ }^{13} \mathrm{C}$ atom $\%$ were regarded as real enrichments against natural ${ }^{13} \mathrm{C}$ composition. Using the dry weight, the relative content of carbon (\% DW) and the ${ }^{13} \mathrm{C}$ atom $\%$ in excess, we have calculated for each sample the quantity of excess ${ }^{13} \mathrm{C}$ in the sample $\left(\mathrm{mg}^{13} \mathrm{C}\right.$ in excess per shoot) and have calculated the contribution of epiphyte and leaves biomass to this ${ }^{13} \mathrm{C}$ in excess.

For biomass accumulation: Artificial Seagrass Units (ASUs) (PVC band of $1 \mathrm{~cm}$ width and $50 \mathrm{~cm}$ length with a float at the extremity and fixed on a post (Macreadie et al., 2010) were deployed into the meadow to estimate the epiphyte production. After 10 days, ASUs were collected. Each ASU was scrapped with a razor blade (Dauby and Poulicek, 1995), epiphytes were ovendried at $60^{\circ} \mathrm{C}$ for $48 \mathrm{~h}$ and then weighed. This epiphyte biomass was converted into mg C shoot ${ }^{-1}$ (by measurements in the $\mathrm{C}-\mathrm{N}-\mathrm{S}$ elemental analyzer; Vario Micro, Elementar, Germany) and used to calculate the daily production per square meter of substrate.

\section{WHAT ARE THE RIGHT TIMES OF SAMPLING TO HAVE THE SNAPSHOTS OF TRANSCRIPTOME AND PROTEOME RESPONSES TO C-STRESS AND TO LIGHT STRESS (BOTH SUPERSATURATING AND LIMITING IRRADIANCES)?}

For molecular analyses it is essential to setup the post-harvest in a way that does not perturb the ambient conditions and that shortens the time interval between plant sampling and tissue fixing. Here, we set the time intervals as short possible: at least two divers and many operators were required for each sampling. Collected plants were placed in black sealed containers in situ, then attached 
to a lift bag and handed to the operators waiting for samples from the dock for shallow sampling or on the boat for deep sampling. Thanks to this organization, we scored the minimum times from the sea to the lab of $10 \mathrm{~min}$ from shallow sites, $15 \mathrm{~min}$ from $20 \mathrm{~m}$ depth and $20 \mathrm{~min}$ from $30 \mathrm{~m}$ depth. The selection of sampling times along the day were made according to the common assessment for in field analyses and based on light changes as detailed in Table 1.

\section{Incorporation of genomics tools}

To incorporate gene expression analysis in the study of the main metabolic pathways involved in carbon budget, two different approaches were taken.

First, total transcriptome profiling was obtained using an Illumina next generation sequencing platform (Illumina GAIIx) available at the Genomics Research Centre (CRA_GPG, Fiorenzuola D'Arda, PC, Italy). High quality total RNA was extracted from pulled leaves from four individual shoots, two of which were collected at $5 \mathrm{~m}$ depth $(12.00$ and 18.30) and the other two at $20 \mathrm{~m}$ depth (12.00 and 18.30). Four complementary DNA (cDNA) libraries were prepared and run in a single Illumina GAIIx plate. Fragments were assembled in longer consensus sequences (contigs) and the following bioinformatic analysis allowed the identification of expressed genes through the annotation of contigs against public databases. All ESTs obtained will be stored in a new database, which will be made available to the scientific community. ESTs from the four samples were compared in order to find differentially expressed genes at the two depths and in two different time points. The set of differentially expressed genes was related to the physiological performances of the plant in the different conditions, and will serve as the basis for selecting sets of environmental responsive genes.

Second, expression levels of a set of genes encoding for molecular components of the photosynthetic and respiration apparatus were evaluated by RT-qPCR. Candidate genes have been selected according to their role in the different phases and in the different compartments of both processes (Table 2). For photosynthesis, we selected as genes of interest two structural components of Photosystem I (PSI), three genes encoding for subunits of PSII, two genes encoding for antenna proteins for each of the two LightHarvesting complexes (LHCI and LHCII), one component of the chloroplast electron transport chain (Ferredoxin), and the gene encoding for RuBisCO small subunit. In order to investigate the photo-protective capacities of $P$. oceanica, we analyzed also the expression levels of one of the two key enzyme of Xanthophyll Cycle. Among those, nine genes (Table 2) had already been utilized in Ruocco et al. (2012) for assessing gene expression along the bathymetric gradient in a P. oceanica population located in the Island of Ischia (Gulf of Naples, Italy).

For respiration we considered, three genes coding for proteins involved in the mitochondrial electron transport chain, one gene coding for a protein part of the ubiquinol-cytochrome $c$ reductase complex and one gene involved in the tricarboxylic acid cycle.

Gene expression of selected genes has been evaluated by RTqPCR, in relation to the expression of one reference gene (L23) selected among those previously identified in P. oceanica (Serra et al., 2012). The analysis has been performed on three individual samples collected along daily cycles at three different depths $(5,20$, and $30 \mathrm{~m}$; Table 1$)$. Leaf tissue was cleaned from epiphytes and immediately stored in RNAlater ${ }^{\circledR}$ Tissue Collection (AMBION, life technologies) in order to prevent RNA degradation. Total RNA extraction was performed using 60-100 mg wet weight tissue, according to the Aurum ${ }^{\mathrm{TM}}$ Total RNA Mini Kit (BIORAD) manufacturer's instructions. RNA quantity and quality was assured by NanoDrop (ND-1000 UV-Vis spectrophotometer; NanoDrop Technologies) and 1\% agarose gel electrophoresis. $500 \mathrm{ng}$ of each RNA sample, were retro-transcribed in cDNA on GeneAmp PCR System 9700 (Perkin Elmer), with the iScrip$\mathrm{t}^{\mathrm{TM}} \mathrm{CDNA}$ synthesis kit (BIO-RAD), following the manufacturer's instructions.

RT-qPCR reactions were performed in MicroAmp Optical 384Well reaction plate (Applied Biosystem) with Optical Adhesive Covers (Applied Biosystem) in a Viia7 Real Time PCR System (Applied Biosystem) using Sybr Green as fluorescent detection chemistry. RT-qPCR amplifications were conducted in $10 \mu \mathrm{l}$ reaction volumes containing $5 \mu \mathrm{l}$ of Fast Start SYBR Green Master Mix (Roche), $1 \mu \mathrm{l}$ of cDNA template and $0.7 \mathrm{pmol}_{\mu \mathrm{l}^{-1}}$ of each primer. Thermal profile was obtained as follows: $95^{\circ} \mathrm{C}$ for $10 \mathrm{~min}, 40$ times $95^{\circ} \mathrm{C}$ for $15 \mathrm{~s}$ and $60^{\circ} \mathrm{C}$ for $1 \mathrm{~min}, 72^{\circ} \mathrm{C}$ for $5 \mathrm{~min}$. For determining the specificity of the reaction, the melting curve of each amplicon from 60 to $95^{\circ} \mathrm{C}$ was also detected. The expression levels of each target gene were determined with REST tool (Relative expression software tool) (Pfaffl et al., 2002). Statistical analysis was performed using GraphPad Prism version 4.00 for Windows (GraphPad Software, San Diego, CA, USA).

The same shoots have been utilized to perform proteomics and a number of different analyses involving the other approaches utilized in the present project (Figure 1).

\section{Incorporation of proteomic tools}

The key step for proteomic analysis of marine plants, that must integrate with genomics and physiology, is the careful screening of target organs or tissues in which will address the proteomic study; leaf tissue is the eligible biological sample in seagrasses because leaves drive primary metabolism, provide the water and ions uptake in the place of roots (Kraemer et al., 1997), their sampling is not destructive for plants (Gobert et al., 2012); protein extraction from adult leaf tissues gives best results in term of pattern reproducibility among the biological replicates than those from intermediate and young leaves belonging the same plants (Dattolo et al., submitted; Spadafora et al., 2008).

Protein extraction and electrophoresis. The next step is process the samples up to a step that allows the safe transport for subsequent molecular analyses. This is the final challenge. The multisteps protocol we adopted to extract proteins allowed us to obtain anhydrous tissue powders in which the proteins are denatured and the proteolytic degradations are inhibited. Tissue samples (see Table 1) have been shipped in this shape to the home laboratory. Here, proteins were extracted from tissue powder and purified following the protocol optimized for $P$. oceanica leaves 
Table 2 | List of genes analyzed for assessing gene expression through RT-qPCR.

\begin{tabular}{|c|c|c|c|}
\hline Metabolic pathway & Gene & Protein & Function \\
\hline \multicolumn{4}{|l|}{ PHOTOSYNTHESIS } \\
\hline \multirow[t]{2}{*}{ PSII } & psbA & D1 & Photosystem II 32kDa thylakoid membrane protein. \\
\hline & & & One of the two reaction center proteins of photosystem II \\
\hline PSII & $\mathrm{psbD}$ & D2 & $\begin{array}{l}\text { Photosystem II 34kDa protein. One of the two reaction center proteins of } \\
\text { photosystem II, it is needed for assembly of a stable PSII complex }\end{array}$ \\
\hline \multirow[t]{2}{*}{ PSII } & PsbS & CP22 & Photosystem II 22kDa protein, chloroplastic. \\
\hline & & & Seems to be involved in non-photochemical quenching (NPQ) \\
\hline \multirow[t]{2}{*}{ PSI } & PsaJ & PSI-J & Photosystem I reaction center subunit IX. \\
\hline & & & May help in the organization of the psaE and psaF subunits \\
\hline \multirow[t]{2}{*}{ PSI } & PsaG & PSI-G & Photosystem I reaction center subunit V, chloroplastic. \\
\hline & & & Function not known \\
\hline $\mathrm{LHCl}$ & CAB-6A & LHCl type I CAB-6A & $\begin{array}{l}\text { Chlorophyll a-b binding protein, chloroplastic. The light-harvesting complex } \\
\text { (LHC) captures and delivers excitation energy to associated photosystems }\end{array}$ \\
\hline $\mathrm{LHCl}$ & LHCA4 & LHCl type III CAB-4 & Chlorophyll a-b binding protein, chloroplastic. \\
\hline LHCII & CAB-151 & LHCII type II CAB-151 & Chlorophyll a-b binding protein, chloroplastic. \\
\hline LHCII & LHCB4.2 & LHCB4.2 & Chlorophyll a-b binding protein, chloroplastic. \\
\hline $\begin{array}{l}\text { Chloroplastic electron } \\
\text { transport chain }\end{array}$ & SEND33 & Ferredoxin-1 & $\begin{array}{l}\text { Ferredoxins are iron-sulfur proteins that transfer electrons in a wide variety } \\
\text { of metabolic reactions }\end{array}$ \\
\hline Carbon dioxide fixation & SSU5B & RuBisCO small chain 5B & $\begin{array}{l}\text { RuBisCO catalyzes the carboxylation of D-ribulose-1,5-bisphosphate and } \\
\text { the oxidative fragmentation of the pentose substrate }\end{array}$ \\
\hline $\begin{array}{l}\text { Xantophyll cycle } \\
\text {-photoprotection }\end{array}$ & ZEP & Zeaxanthinepoxidase & $\begin{array}{l}\text { Zeaxanthin epoxidase plays an important role in the xanthophyll cycle and } \\
\text { abscisic acid (ABA) biosynthesis }\end{array}$ \\
\hline \multicolumn{4}{|l|}{ RESPIRATION } \\
\hline $\begin{array}{l}\text { Ubiquinol-cytochrome } c \\
\text { reductase complex }\end{array}$ & FES1 & $\begin{array}{l}\text { Ubiquinol-cytochrome } c \\
\text { reductase iron-sulfur } \\
\text { subunit }\end{array}$ & $\begin{array}{l}\text { Component of the ubiquinol-cytochrome } c \text { reductase complex (complex III } \\
\text { or cytochrome } b-c 1 \text { complex), which is a respiratory chain that generates } \\
\text { an electrochemical potential coupled to ATP synthesis }\end{array}$ \\
\hline $\begin{array}{l}\text { Mitochondrial electron } \\
\text { transport chain }\end{array}$ & COX5B & $\begin{array}{l}\text { Cytochrome c oxidase } \\
\text { subunit } 5 B\end{array}$ & $\begin{array}{l}\text { One of the nuclear-coded polypeptide chains of cytochrome } c \text { oxidase, the } \\
\text { terminal oxidase in mitochondrial electron transport }\end{array}$ \\
\hline $\begin{array}{l}\text { Mitochondrial electron } \\
\text { transport chain }\end{array}$ & AOX1A & Alternative oxidase1A & $\begin{array}{l}\text { Catalyzes the cyanide-resistant oxidation of ubiquinol and the reduction of } \\
\text { molecular oxygen to water. Increases respiration when the cytochrome } \\
\text { respiratory pathway is restricted }\end{array}$ \\
\hline $\begin{array}{l}\text { Mitochondrial electron } \\
\text { transport chain }\end{array}$ & $\mathrm{SDH} 2-2$ & $\begin{array}{l}\text { Succinate dehydrogenase } \\
\text { [ubiquinone] iron-sulfur } \\
\text { subunit } 2\end{array}$ & $\begin{array}{l}\text { Iron-sulfur protein (IP) subunit of succinate dehydrogenase (SDH), involved } \\
\text { in complex II of the mitochondrial electron transport chain and responsible } \\
\text { for transferring electrons from succinate to ubiquinone (coenzyme Q) }\end{array}$ \\
\hline Tricarboxylic acid cycle & $\mathrm{CMDH}$ & Malate dehydrogenase & Catalytic activity: (S)-malate $+\mathrm{NAD}+=$ oxaloacetate $+\mathrm{NADH}$ \\
\hline
\end{tabular}

Both photosynthetic and respiratory genes are shown. Gene names based on best scoring hits obtained blasting sequences against the Swiss-Prot database.

(Spadafora et al., 2008). Briefly, $1 \mathrm{~g}$ of mature leaf tissue, frozen in N2, was ground to a fine powder and dissolved in $20 \%$ aqueous TCA (3-chloro-acetic acid) with $1 \%$ proteases inhibitor PMSF (phenylmethylsulfonylfluoride), to eliminate contaminants and precipitate proteins from leaf tissue. The extracted proteins were then treated with a phenol solution to isolate and purify the proteins from non-protein substances. Protein samples from all samples were processed on 1D SDS-PAGE; the Laemmli buffer system was used to cast a $6 \%$ stacking gel and $12.5 \%$ resolving gel. After denaturation at $100^{\circ} \mathrm{C}$ for $3 \mathrm{~min}$, proteins were resolved at constant $200 \mathrm{~V}$ in a Bio-Rad mini Protean II apparatus. Peptide bands were quantified using Quantity One software (Bio-Rad). For each lane, area, and density of bands were calculated. Band volume was the product of band area and density. After background subtraction, band volume was normalized as the percentage of the total volume of protein bands on the same lane. The normalized 
volume (NV) of single band on the multiple gels from single depth and among samples was calculated, which was reproducible with $90 \%$ accuracy.

Orbitrap-LC-MS/MS and protein identification. Gel slides from each SDS-PAGE were cut in six slices and digested enzymatically with trypsin. Tryptic peptides were analyzed by liquid chromatography-tandem mass spectrometry (LC-MS/MS) using a high resolution LTQ-Orbitrap spectrometer (Thermo). Chromatography separations were conducted on a Waters XBridge C18 column $(300 \mu \mathrm{m}$ I.D. $\times 100 \mathrm{~mm}$ length and $3.5 \mu \mathrm{m}$ particle size $)$, using a linear gradient from 5 to $90 \% \mathrm{ACN}$, containing $0.1 \%$ formic acid with a flow of $4 \mu \mathrm{min}^{-1}$, including the regeneration step, one run lasted $70 \mathrm{~min}$. Acquisitions were performed in the data-dependent MS/MS scanning mode (full MS scan range of 250-1800 $\mathrm{m} \mathrm{z}^{-1}$ followed by full MS/MS scan for the most intense ion from the MS scan).

This yielded de novo protein sequences suitable for database searching. At first, peptide sequences generated by mass spectrometry were searched using GPM software (Global Proteome Machine) against plant databases. Peptide sequences, that were not identify with the method above, were further searched to GPM website using X!Tandem algorithm against the local database sequences building with all available $P$. oceanica and $Z$. marina sequences found in NCBI, Uniprot, and DrZompo databases (see Dattolo et al., submitted).

1-DE Free-label approach and relative quantification by spectral count. The Figure 4A shows the 1-DE-SDS separation of samples and the gel slices at ranges of molecular weight that were compared to detect differentially expressed proteins. The samples represent total protein extracts from $P$. oceanica adult leaves at different depths along the daily cycle. The differentially expression of proteins were evaluated by the labeling-free approach (Zhang and Wang, 2009). The workflow employed is described in the Figure 4B. After the proteins were digested with trypsin, the peptides obtained were analyzed Orbitrap-LC-MS/MS in singly charged ion production mode, and the peptide fingerprint was acquired using a high-mass-accuracy q-TOF instrument. In the spectral counting approach, relative protein quantification is achieved by comparing the number of identified MS/MS spectra from the same protein in each of the multiple LC-MS/MS datasets. This is possible because an increase in protein abundance typically results in an increase in the number of its proteolytic peptides, and vice-versa. This increased number of (tryptic) digests then usually results in an increase in protein sequence coverage, the number of identified unique peptides, and the number of identified total MS/MS spectra (spectral count) for each protein (Schulze and Usadel, 2010).

The differentially expressed peptides were analyzed using the fingerprint approach, and the differentially expressed proteins were then identified. The peptide sequences of the differentially expressed proteins were confirmed by MS/MS. Table 3 shows the differentially expressed proteins characterized in slices $4^{\mathrm{a}}$ and $4^{\mathrm{b}}$ corresponding to middle molecular weight peptides in the 1-DE-PAGE samples from -5 and $-30 \mathrm{~m}$ at $13.00 \mathrm{~h}$ of same day. The identification score are reported with the peptide sequence and number of spectra are used to evaluate the level of protein expression. Many identified protein were found to be differentially expressed in this pair of gel slices; RuBisCo large subunits were about twofold over-expressed in shallow leaves relative to the deep leaves. However, all differentially expressed peptide among depths along daily cycle were detected by this approach.

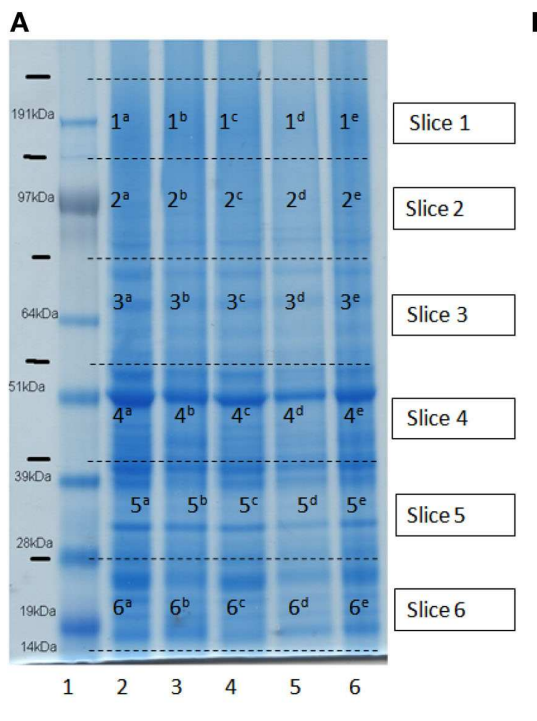

FIGURE 4 | (A) 1-DE gel electrophoresis of leaf protein extracts from three depths. Dotted lines indicate each gel slice analyzed by labeling-free approach; Lane (1) markers; lane (2) 8.00 h, 3 m depth; lane (3) $8.00 \mathrm{~h}$,

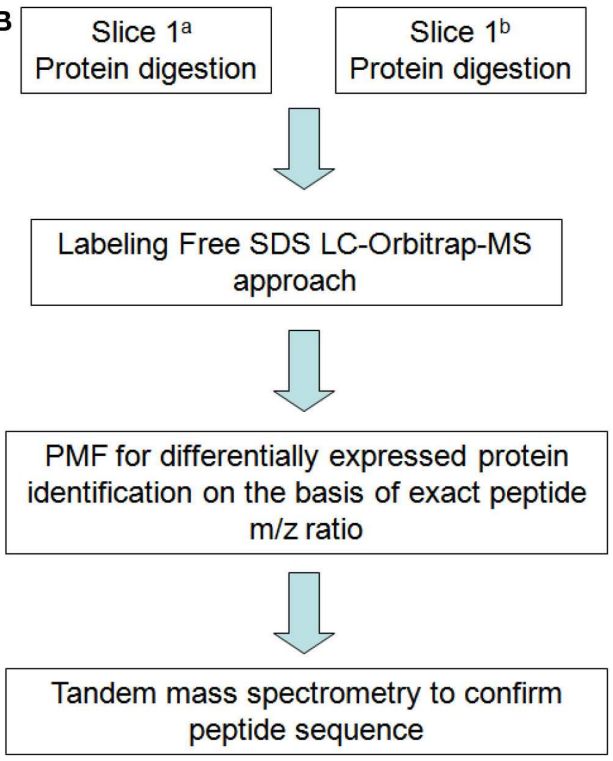

$30 \mathrm{~m}$ depth; lane (4) $13.00 \mathrm{~h}, 3 \mathrm{~m}$ depth: lane (5) $13.30 \mathrm{~h}, 20 \mathrm{~m}$ depth; lane (6) $13.00 \mathrm{~h}, 30 \mathrm{~m}$ depth. (B) Experimental workflow applied to each pair of gel slices. 
Table 3 | Proteins detected in the slices $4^{c}$ and $4^{d}$ of the 1-DE (Figure 4) by means the label-free approach and spectral counting.

\begin{tabular}{|c|c|c|c|c|c|c|c|c|}
\hline $\log (e)$ & $\log (I)$ & $\%$ (Measured) & $\%$ (Corrected) & unique & spectra & Mr & Accession & Description \\
\hline \multicolumn{9}{|l|}{ (A) } \\
\hline-121 & 5.52 & 18 & 41 & 13 & 40 & 51.4 & $\operatorname{tr|B5WX89|B5WX89\_ 9ARAE~}$ & $\begin{array}{l}\text { Ribulose-biphosphate carboxylase (large } \\
\text { subunit) }\end{array}$ \\
\hline-82.2 & 5.45 & 18 & 49 & 7 & 30 & 54.6 & 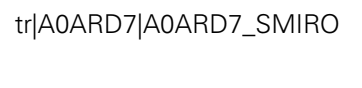 & $\begin{array}{l}\text { Photosystem II CP47 chlorophyll } \\
\text { apoprotein }\end{array}$ \\
\hline-40.9 & 5.15 & 22 & 34 & 4 & 15 & 37.6 & EG_Contig15_1 & Chlorophyll A-B binding protein (CAB) \\
\hline-26.3 & 5.24 & 1.4 & 2 & 4 & 15 & 211.7 & Zoma_B_i00191_2 & $\begin{array}{l}\text { Photosystem I P700 chlorophyll A } \\
\text { apoprotein A1 }\end{array}$ \\
\hline-47.5 & 4.87 & 15 & 19 & 5 & 10 & 53.7 & $\operatorname{tr}|\mathrm{Q} 4 \mathrm{FG}| 4 \mid \mathrm{Q} 4 \mathrm{FGI}$ _TYPLA & ATP synthase subunit beta \\
\hline & & & & & & & & dehydrogenase A, chloroplastic \\
\hline-19 & 4.82 & 4.5 & 7 & 2 & 5 & 88.2 & Zoma_C_c61233_6 & ATP synthase subunit alpha mitochondrial \\
\hline-12 & 4 & 3.4 & 5 & 2 & 5 & 80 & sp|A2YWQ1|HSP81_ORYSI & Heat shock protein 81-1 \\
\hline-19 & 4.34 & 7.2 & 9 & 3 & 5 & 59.1 & sp|P19023|ATPBM_MAIZE & ATP synthase subunit beta, mitochondrial \\
\hline-10.9 & 4.55 & 2.9 & 5 & 2 & 4 & 104.4 & $\operatorname{tr}|\mathrm{Q} 43275| \mathrm{Q} 43275 \_Z O S M R$ & Putative plasma membrane $\mathrm{H}+$-ATPase \\
\hline-22.6 & 4 & 12 & 25 & 3 & 4 & 39.6 & sp|Q4FFP4|PSBD_ACOAM & Photosystem II D2 protein \\
\hline-8.9 & 4 & 6.2 & 23 & 2 & 4 & 38.9 & sp|Q3V554|PSBA_ACOCL & Photosystem $\mathrm{Q}(\mathrm{B})$ protein \\
\hline-12.7 & 4.47 & 15 & 25 & 2 & 4 & 24.2 & sp|P05642|CYB6_MAIZE & Cytochrome $b 6$ \\
\hline \multicolumn{9}{|l|}{ (B) } \\
\hline-113 & 5.35 & 20 & 55 & 8 & 29 & 54.9 & tr|H6TGJ9|H6TGJ9_9LILI & Photosystem II CP47 protein \\
\hline-18.5 & 4 & 5.3 & 7 & 4 & 7 & 83.7 & tr|Q8W0Q7|Q8W0Q7_SORBI & Methionine synthase protein \\
\hline-7.9 & 4 & 2.6 & 3 & 1 & 5 & 93.9 & 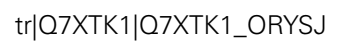 & Elongation factor \\
\hline-8.1 & 4 & 6.2 & 23 & 2 & 5 & 38.9 & sp|Q3V554|PSBA_ACOCL & 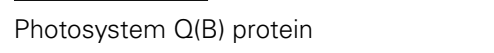 \\
\hline-18.5 & 4.47 & 1.7 & 3 & 3 & 4 & 240.7 & Zoma_C_c64621_5 & $\begin{array}{l}\text { Photosystem I P700 chlorophyll a } \\
\text { apoprotein A1 }\end{array}$ \\
\hline-26.9 & 4.63 & 4.3 & 9 & 2 & 4 & 54.7 & $\operatorname{tr||1H3A2||1H3A2\_ BRAD|~}$ & Uncharacterized protein \\
\hline-10.5 & 4 & 10 & 12 & 2 & 4 & 28.9 & Pooc_Contig132_3 & S-norcoclaurine synthase OS \\
\hline-7.8 & 4.13 & 0.7 & 1 & 1 & 3 & 257 & sp|B9FK36|ACC2_ORYSJ & Acetyl-CoA carboxylase 2 \\
\hline-26.8 & 4 & 5.9 & 6 & 1 & 2 & 39.6 & sp|Q4FFP4|PSBD_ACOAM & Photosystem II D2 protein \\
\hline
\end{tabular}

Statistical parameters and protein description are reported for shallow (A) and deep (B) plants. Proteins are sorted by number of spectra in both samples. The underline protiens are detected only in shallow or deep plants.

log(e): the base-10 log of the expectation that any particular protein assignment was made at random (E-value).

$\log (I)$ : the base-10 log of the sum of the fragment ion intensities in the tandem mass spectra used to make this assignment.

$\%$ (measured): the amino acid coverage of the protein in this assignment.

$\%$ (corrected): the amino acid coverage of the protein in this assignment/the coverage corrected for peptide sequences that are unlikely to be observed using normal proteomics methods.

Unique: the number of unique peptide sequences associated with this protein assignment.

Spectra: number of spectra assigned to the unique peptides for this protein.

Mr: the molecular mass of the entire protein sequence, in kiloDaltons. 


\section{Incorporation of genetic tools}

Meadows of $P$. oceanica have been extensively genotyped in the last few years overall Mediterranean Sea, using a set of 13 microsatellite markers. Variable levels of genetic diversity have been recorded, spanning from complete clonality (e.g., Ruggiero et al., 2002; Arnaud-Haond et al., 2012) to high diversity (e.g., Arnaud-Haond et al., 2007; Tomasello et al., 2009; Serra et al., 2010). Although the role of genetic and genotypic diversity of seagrass meadows on ecosystem functioning and on meadow resistance and resilience, have been debated in the recent literature (e.g., Ehlers et al., 2008; Arnaud-Haond et al., 2010), the assessment of genetic and genotypic variation, would allow to better evaluate factors underlying plasticity in the physiological response of the studied meadow. In order to do that, 20 samples from each of the two depths (5 and $20 \mathrm{~m}$ ) were collected randomly and genotyped with the available putatively neutral microsatellite markers, as in Migliaccio et al. (2005). Allelic diversity, heterozygosity, and genotypic diversity have been compared between the two depths as well as between the STARESO meadows and other meadows at increasing distance from the study area. Levels of gene flow among meadows have also been assessed. Moreover, single shoots sampled for gene and protein expression analysis, and for photosynthesis and respiration measurements, have been genotyped, in order to investigate possible relationships between differences in physiological performances and difference in allelic composition of individual genotypes.

Shoots collected for the analysis with putatively neutral microsatellites markers, have also been genotyped with 51 ESTlinked microsatellite (EST-msat) loci, following the protocol in D'Esposito et al. (in press). The EST-msat loci were assembled in four multiplex PCR reactions, capillary electrophoresis was performed in a Applied Biosystems 3730 DNA Analyzer and electropherograms were automatically scored using the software Peak Scanner (ABI). Search for outliers was performed comparing the two depths and other populations at variable distance from the study site. Ad hoc software was utilized and only loci positive to different statistical approaches were retained as real. Function of EST regions linked to outlier loci were evaluated in order to assess if depth has an effect on selecting genes related to carbon budget.

\section{NON-INVASIVE PHYSIOLOGICAL ANALYSIS}

Historically, many estimates of productivity of larger systems in nature has been done by extrapolating data from measurements from a small number of plants (or parts of plants) made in enclosures in the laboratory. However, these data have been shown to often yield values largely deviating from data obtained at more natural conditions. Also, the metabolic processes in plants are often linked to diel cycles, and thus often dramatically different at different times of the day, even if all environmental parameter might be similar. Thus it is important to follow these metabolic processes in situ, and during a longer time, as to be able to better estimate their true rates.

\section{Mitochondrial respiration and photosynthesis}

Surprisingly enough, there is a shortage of data on how much of the $\mathrm{CO}_{2}$ that is fixed through photosynthesis in seagrasses that are lost to the plant, or the system, by respiration. Seagrasses, like terrestrial plants, have both above- and below-ground tissues, making it much harder to measure rates of respiration of the underground roots and rhizomes, especially in situ. Therefore we are now incorporating this factor when measuring whole-plant or plant- community-based metabolism.

\section{Incorporation of environmental sensors}

Major obstacles in estimating community metabolism from physiological measurements on single plants are the scale in time and space. However, by the accurate measurement of key parameters, e.g., light and temperature, over the area and at different times of the day, and linking those to well-studied proxies for productivity, e.g., ETR, the scaling up of metabolic rates to meadow scale can be possible. Recent advances in automated fluorometery systems for in situ use (e.g., Shutter Fluorometer, Aquation, Australia) have enabled us to obtain regular measurements of both the effective quantum yield of photochemical energy conversion, PAR, and non-photochemical quenching. Using yield and PAR values we can calculate ETR and obtain a diel trace of ETR while avoiding artifacts due to transporting material away from the site of interest. The partitioning of non-photochemical quenching into several processes enabled by temporary dark-acclimation using the shutter provides additional insights into the nature of the physiological response to light over the course of a day.

Minilog TR temperature recorders, with a resolution of $0.2^{\circ} \mathrm{C}$ and an accuracy of $\pm 0.3^{\circ} \mathrm{C}$, were deployed at $3,10,20$, and $30 \mathrm{~m}$ depth in canopy of the $P$. oceanica meadow (temporal data acquisition of every $30 \mathrm{~min}, \mathrm{GMT}+1$ ).

The acoustic signals were transmitted from a Lubell LL916C underwater speaker installed $2 \mathrm{~m}$ above the sea bottom in a site with water depth $8.5 \mathrm{~m}$ to three hydrophones Marsensing SR-1 moored in $21.5 \mathrm{~m}$ water column, 8,4 , and $2 \mathrm{~m}$ above the water column (Figure 5). The distance between the source and hydrophones mooring was $\sim 122 \mathrm{~m}$. The acoustic data were acquired in two periods of about 2.5 days, separated by a bad weather event. The repetition rate of the signals was set to $15 \mathrm{~min}$ during the first period and $5 \mathrm{~min}$ in the second period to attain a higher time resolution. The signals were transmitted in three different frequency bands: low frequency band $(400-800 \mathrm{~Hz})$, medium frequency band $(1500-3500 \mathrm{~Hz})$, and frequency band $(6500-8500 \mathrm{~Hz})$. The instantaneous energy of the received signals and its half-hour running average was computed (Figure 6). We used the optode data from a mooring that has been deployed since August 2006 (Champenois and Borges, 2012). The mooring is located over the P. oceanica meadow at $10 \mathrm{~m}$ depth $\left(8.733^{\prime} \mathrm{E}\right.$ $\left.42.567^{\prime} \mathrm{N}\right)$ close to the STARESO research station. Aanderaa $\mathrm{O}_{2}$ optodes (3835) mounted on Alec Instruments loggers were deployed at 4.5, 7.0, and $9.5 \mathrm{~m}$ depth. Oxygen saturation level and temperature were measured and logged at hourly intervals, to accommodate the typical duration of deployments ( $\sim 3$ months) and lithium battery life at that sampling rate ( $\sim 5$ months). Mooring data are interpreted in conjunction with other data, among which wind speed measured with an anemometer (Thies Clima) deployed on top of one of buildings of the STARESO station (at $11.8 \mathrm{~m}$ height) at a distance of about $100 \mathrm{~m}$ from the mooring. The temporal variations of the instantaneous energy of the accoustic signals and of the optodes was similar (Figure 6). 

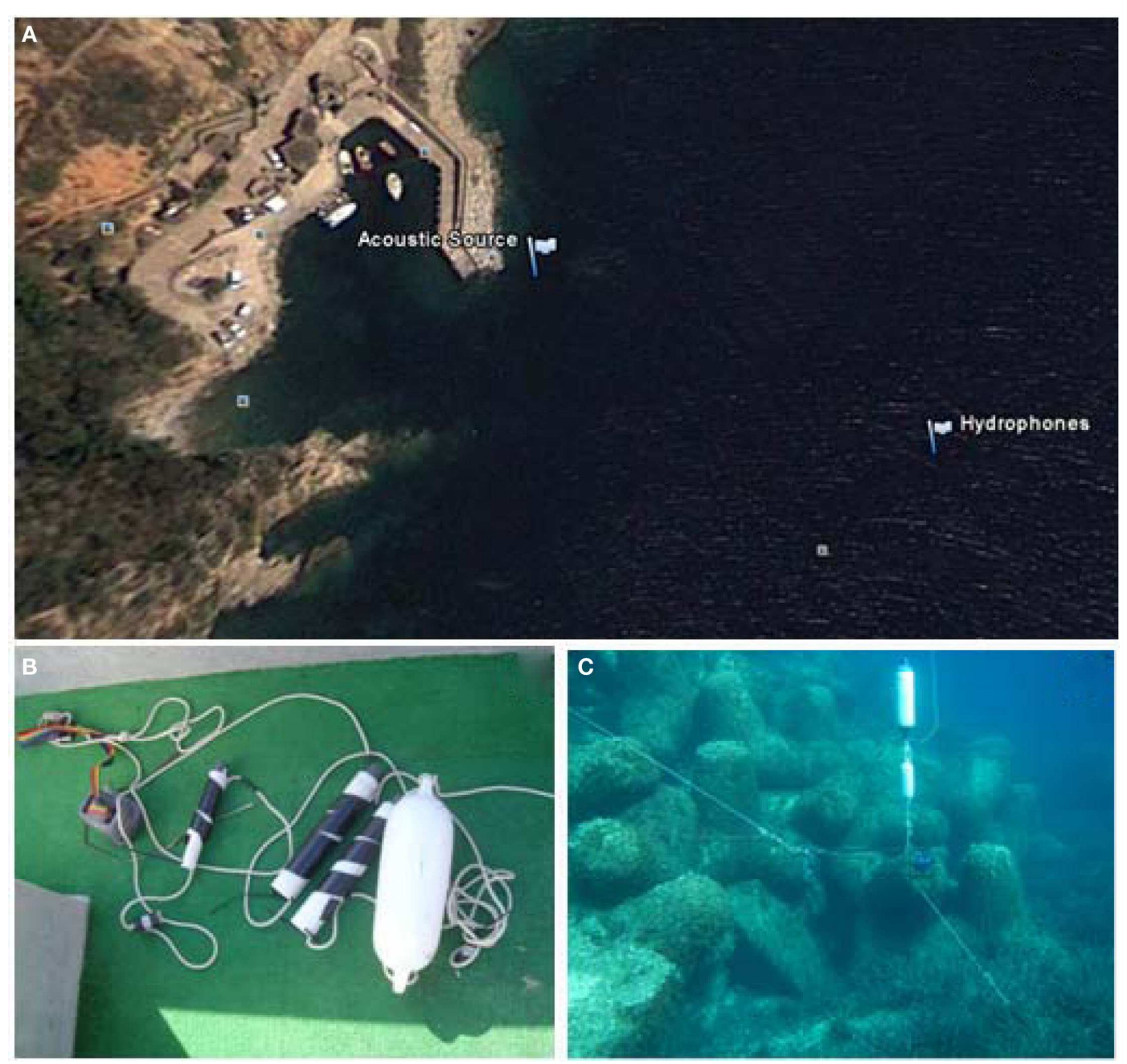

FIGURE 5 | Experimental area showing the location of the source and the hydrophones, (A) the source mooring and the Marsensing SR-1 self-recording hydrophones used in the underwater experiments $(B, C)$.

The time evolution of the received energy show high correlation with the photosynthesis activity: during the night the received energy is higher and its variability is low, during the daylight period the signal is highly attenuated with a remarkable fast fall of energy at sunrise. During daylight the variability of the received energy higher than during the night, it is observed an energy minimum at noon. Those results are in line with previous ones presented in works (Hermand and Alberotanza, 2000; Hermand, 2003; Wilson et al., 2012) and show the potential usage of acoustic method to track the integrated space-time variability of photosynthesis rate at community level.

\section{EXPECTED RESULTS \\ HOW DOES MITOCHONDRIAL RESPIRATION CHANGE OVER THE DAY; IS IT CHANGING IN CORRELATION WITH THE LIGHT AND IN THAT CASE HOW?}

The respiration changed with the time of day, following distinct diel cycles persistently over the 6 days the measurements was performed. The patterns of respiration were similar for the plants from the two depths, although slightly shifted in time. The respiration was always higher during the day, and the plants at the $20 \mathrm{~m}$ station had a peak in respiration around noon, while the plants from the $5 \mathrm{~m}$ station had their highest respiratory rates at around $15-18 \mathrm{~h}$. Similarly, the lowest respiration for the $20 \mathrm{~m}$ plants was measured at six in the morning, while for the $20 \mathrm{~m}$ plants the lowest rates were at $9 \mathrm{~h}$.

\section{WHAT IS THE RELATIVE IMPORTANCE OF PLANT RESPIRATION FOR THE CARBON BUDGET OF THE MEADOW?}

In general, irradiance (above canopy) peaked around noon, at about $900 \mu \mathrm{mol}$ quanta $\mathrm{m}^{-2} \mathrm{~s}^{-1}$ at $5 \mathrm{~m}$ and at about $170 \mu \mathrm{mol}$ quanta $\mathrm{m}^{-2} \mathrm{~s}^{-1}$ at $20 \mathrm{~m}$. In situ ETR measurements peaked at these light levels, at 26.3 and $10.6^{\mathrm{e}-} \mathrm{m}^{-2} \mathrm{~s}^{-1}$, respectively. NCP peaked at around $8.6 \mu \mathrm{mol} \mathrm{O}_{2} \mathrm{~m}^{-2} \mathrm{~s}^{-1}$ at $3 \mathrm{~m}$ and at about $0.4 \mu \mathrm{mol}$ $\mathrm{O}_{2} \mathrm{~m}^{-2} \mathrm{~s}^{-1}$ at $20 \mathrm{~m}$. Then the respiration of the above-ground tissue was substantially higher than that of the below-ground tissue. As an average the above-ground tissue had a respiration rate 4.6 times higher than the rate of the below-ground tissue. 


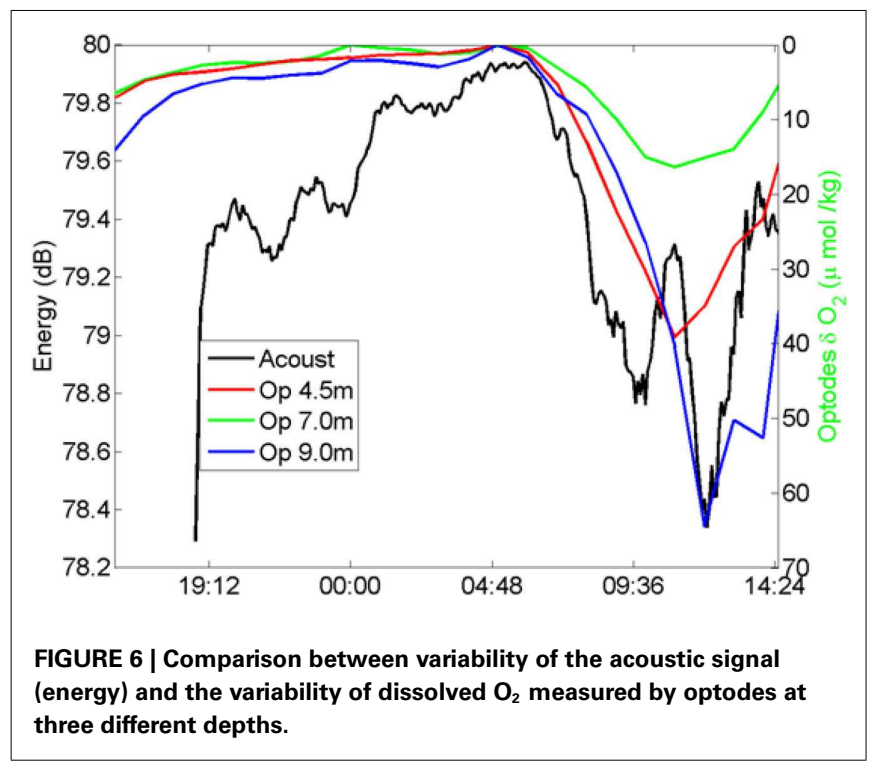

\section{HOW MUCH DO THE EPIPHYTIC COMMUNITIES ON THE P. OCEANICA LEAVES CONTRIBUTE TO THE OVERALL C-FLUX?}

Change in biomass over the time is regularly used to estimate primary production in seagrasses. ASUs are simple and inexpensive and have the advantage of requiring minimal equipment. However, the ASU technique underestimates net productivity of epiphytes since it does not account for biomass losses due to excretion, decomposition, and harvest by grazers. ${ }^{13} \mathrm{C}$ tracer incorporation into benthic chambers is simple but ASU and ${ }^{13} \mathrm{C}$ tracer incorporation require sophisticated instrumentation for analytical measurements ( $\mathrm{C}-\mathrm{N}-\mathrm{S}$ elemental analyzer and isotopic ratio mass spectrometer).

Seagrasses with a long life-span, such as $P$. oceanica support a complex community of epiphytic organisms and a multistratified community of diatoms and other microorganisms, crustose corallines, or crustose brown algae, sessile animals such as bryozoans, erect photophilous brown algae, and filamentous red algae (Van der Ben, 1971). The epiphyte community (species, biomass, algae vs. animals) and production is related to abiotic factors like light, water motion, temperature, nutriments and is related to biotic factors such as grazing. The epiphyte biomass is mainly related to substrate leaf availability, it decreases with increasing depth and increases from winter to summer (Lepoint et al., 1999). Light plays a strong role, the depth range restricting some epiphytic algae, in contrast, crustose corallines tolerate light-level variability and may colonize the entire length of $P$. oceanica leaves across the complete depth range of the meadow (Lepoint et al., 2007).

As the spatial structure of the epiphytic community occurs at different scales in relation to bathymetry $(100 \mathrm{~m})$, to meadow patchiness $(10 \mathrm{~m})$, to patch structure $(1 \mathrm{~m})$, and to the shoot itself $(10 \mathrm{~cm})$, we expected a large spatial variation in epiphytic community contribution to the overall C-flux. We also expect a day to day variability (only measurable by incubation approach) linked to light availability and to meteorological events. In the P. oceanica meadow, hourly epiphyte production is higher or similar to leaf production but epiphyte biomass accounted from 5 to $50 \%$ of the total above-ground biomass (Gobert et al., 2006) so epiphyte carbon assimilation ranges between 30 and $50 \%$ of the total $P$. oceanica shoot production (Modigh et al., 1998).

\section{HOW DOES THE EXPRESSION OF SPECIFIC GENES AND PROTEINS CHANGE IN RELATION TO PHOTOSYNTHETIC ACTIVITY?}

We expect changes in gene expression to be related to the amount of light available at the different depths during the daily cycles. The relationship between photosynthetic activity and efficiency, calculated by modulated fluorometry, and gene expression, obtained by RT-qPCR, can allow us to test the adaptive response of $P$. oceanica to different light regimes. We expect genes to be down-regulated with low-light. If this is the case, and in the presence of high photosynthetic efficiency at both depths, as suggested by previous unpublished PAM fluorometry data (Dattolo et al., submitted), we will confirm the plant to be shade adapted.

Results from genotyping of the two different stands, will allow us to infer the genetic isolation of plants along the depth gradient. This has already been found by Migliaccio et al. (2005), where plants sampled above and below the summer thermocline were found to be genetically isolated. The use of ESTrelated markers could allow the identification of putative outliers, which would result from positive or balancing selection acting between the two depths. Finally, we aim to relate inter-individual differences in gene expression with genotypic inter-individual differences.

\section{CAN WE CORRELATE CHANGES IN PRODUCTIVITY WITH CHANGES IN THE TRANSCRIPTOME AND IN THE PROTEOME?}

The main question is how good will be the correlations between gene expression and related protein levels, as the correlation vary depending on the system and should be as little as $40 \%$ (Vogel and Marcotte, 2012). There are many processes between transcription and translation and protein stability is a big factor. The half-life of different proteins can vary from minutes to days - whereas the degradation rate of mRNA would fall within a much tighter range, few hours for mRNAs vs. $48 \mathrm{~h}$ for protein (Vogel and Marcotte, 2012). Other factors include the lower rate of mRNA transcription compared to protein translation in cells, where single mRNAs transcribed per hour versus dozens of proteins/mRNA/hr. The biochemical diversity of proteins means that the individual correlation levels with the associated mRNA are going to vary a lot. We decided to consider, as a possible way to overcome the gap, the transcription level data; it can suggest whether or not the protein is present or not and roughly what level to expect to see the protein; i.e., a highly abundant protein will usually have a highly expressed mRNA. Therefore, the transcription data is useful for identifying potential candidates for follow-up work at the protein level and vice-versa.

Results obtained from RNA-Seq will allow the identification of differentially expressed sets of genes, extending the comprehension on the transcriptional regulation of $P$. oceanica in different environmental conditions. Identified regulatory networks and metabolic pathways will be correlated to the response to light and other environmental cues, allowing the identification of putative key genes in the physiological homeostasis of $P$. oceanica. Both RT-qPCR and RNA-Seq results will be correlated with changes in 
protein expression, in order to better identify regulatory networks and metabolic pathways mediating the response to light and depth.

We expect changes in proteins expression among primary metabolisms according to depth and daily light variations. This prospect is corroborated by a previous proteomic study on $P$. oceanica, in which RuBisCo was found to be $30 \%$ under-expressed in low-light acclimated leaves than those grown in high-light (Mazzuca et al., 2009). These findings indicated that light acclimation can affect the biochemical pathways of photosynthetic carbon assimilation. It is well known that during leaf development in land plants, lower levels of RuBisCo are closely tied to alterations in photosynthetic capacities which can strongly reduce the rate of leaf growth (Jiang and Rodermel, 1995). As a result of this impaired metabolism, there is a decrease in overall protein synthesis (Quick et al., 1991). In P. oceanica meadows, corresponding evidence between RuBisCo down-regulation, and decreased leaf length and shoot density were reported (Acunto et al., 2006). Interestingly, reduced leaf elongation was also observed in aquarium plants exposed to shading (Mazzuca, personal communication). These findings provide evidence that reductions in leaf growth may be related to decrease in primary production due the downregulation of RuBisCo, both in plants acclimated to chronic lowlight and in plants exposed to a short periods of shading. This is consistent with observations where leaves acclimated to chronic low-light exhibited lower protein synthesis, as indicated by lower protein yield in comparison to plants exposed to high-light conditions (Filadoro, 2007). We expect also variations in proteins related to photosystems functioning and structure among leaves acclimated to different depths; ultrastructural studies of $P$. oceanica chloroplasts showed that the exposure to chronic low-light drives the rearrangement between the two photosystems in a way that the PSI/PSII ratio is related to RuBisCo down-regulation; this may optimize daily carbon gains under low-light conditions (Mazzuca et al., 2009). The further independent study, whose partial results

\section{REFERENCES}

Acunto, S., Rende, F., Cozza, R., and Innocenti, M. (2006). State of health of Posidonia oceanica meadows along the northern Tyrrhenian coast of Calabria, Italy. Biol. Mar. Med. 13, 8-13.

Arnaud-Haond, S., Duarte, C. M., DiazAlmela, E., Marba, N., Sintes, T., and Serrao, E. A. (2012). Implications of extreme life span in clonal organisms: millenary clones in meadows of the threatened seagrass Posidonia oceanica. PLOS ONE 7:30454. doi:10.1371/journal.pone.0030454

Arnaud-Haond, S., Marba, N., DiazAlmela, E., Serrao, E. A., and Duarte, C. M. (2010). Comparative analysis of stability-genetic diversity in seagrass (Posidonia oceanica) meadows yield unexpected results. Estuar. Coast. 33, 878-888.

Arnaud-Haond, S., Migliaccio, M., Diaz-Almela, E., Teixeira, S., Vliet, M., Alberto, F., et al. (2007).

are reported here, confirmed the down-regulation of RuBisCo in leaves of deep plants; as shown in the Table 3, RuBisCo large subunit has counted higher spectra number in shallow samples than deep ones.

\section{CONCLUDING REMARKS}

Posidonia oceanica meadows are complex ecosystems, whose dynamics, functioning, and evolution result from the interaction of numerous players, and from their response to environmental clues. No single actor plays independently nor is immune from the synergistic or antagonistic effects of the others. Seemingly, no single parameter can give a complete picture of the ecosystem and can be considered alone to fully describe the functioning and predict the fate of a seagrass meadow. The aim of this paper was to describe an integrative approach to the study of carbon cycling in $P$. oceanica meadows, supporting the concept that only a multidisciplinary study can uncover the emerging properties of an ecosystem that would otherwise remain undiscovered. We provide an evaluation of methods that measure the primary productivity of seagrasses, from the molecular (genomics, proteomics) and plant level (photosynthesis and respiration using carbon and oxygen flux techniques), to the community (net community metabolism and respiration) and ecosystem level (use of acoustics to measure oxygen production at large spatial scales and air-water $\mathrm{CO}_{2}$ flux).

\section{ACKNOWLEDGMENTS}

We thank the ESF COST Action (ES 0906) Seagrass Productivity: From Genes to Ecosystem Management for the funds provided and all the participants to the October 2011 WG1 and WG2 Workshop: linking seagrass productivity, community metabolism, and ecosystem carbon fluxes, for their fruitful contribution during the workshop. We thank Alexandre Volpon for his willingness to solve hitches.

by pulse amplitude modulated (PAM) fluorometry. Aquat. Bot. 66, 69-76.

Beer, S., Vilenkin, B., Weil, A., Veste, M., Susel, L., Eshel, A. (1998). Measuring photosynthesis in seagrasses by pulse amplitude modulated (PAM) fluorometry. Mar. Ecol. Prog. Ser. 174, 293-300.

Bergmann, N., Winters, G., Rauch, G., Eizaguirre, C., Gu, J., Nelle, P., et al. (2010). Population-specificity of heat stress gene induction in northern and southern eelgrass Zostera marina populations under simulated global warming. Mol. Ecol. 19, 2870-2883.

Bouck, A., and Vision, T. (2007). The molecular ecologist's guide to expressed sequence tags. Mol. Ecol. 16, 907-924.

Bouderesque, C. F., and Meinesz, A. (1982). Découverte de l'herbier de Posidonie. Cahiers $d u$ Parc National de Port-Cros 4, 1-79.
Boudouresque, C. F., Bernard, G. Bonhomme, P., Charbonnel, E., Diviacco, G., Meinesz, A., et al. (2006). Préservation et Conservation des Herbiers à Posidonia oceanica. Monaco: Ramonge pub. 1-202 ISBN 2-905540-30-3

Boudouresque, C. F., Bernard, G., Pergent, G., Shili, A., and Verlaque, M. (2009). Regression of Mediterranean seagrasses caused by natural processes and anthropogenic disturbances and stress: a critical review. Bot. Mar. 52, 395-418.

Champenois, W., and Borges, A. V. (2012). Seasonal and inter-annual variations of community metabolism rates of a Posidonia oceanica seagrass meadow. Limnol. Oceanogr. 57, 347-361.

Dauby, P., and Poulicek, M. (1995). Methods for removing epiphytes from seagrasses: SEM observations on treated leaves. Aquat. Bot. 52, 217-228. 
D’Esposito, D., Orsini, L., and Procaccini, G. (in press). Development of 51 novel EST-linked microsatellites in the Mediterranean seagrass Posidonia oceanica. Mar. Ecol. Resour.

Duarte, C. M. (1999). Seagrass ecology at the turn of the millennium: challenges for the new century. Aquat. Bot. 65, 7-20.

Ehlers, A., Worm, B., and Reusch, T. B. H. (2008). Importance of genetic diversity in eelgrass Zostera marina for its resilience to global warming. Mar. Ecol. Prog. Ser. 355, 1-7.

Ferro, M., Brugiere, S., Salvi, D., Seigneurin-Biery, D., Court, M., Moyet, L., et al. (2010). AT_CHLORO: a comprehensive chloroplast proteome database with subplastidial localization and curated information on envelope proteins. Mol. Cell. Proteomics 9, 1063-1084.

Filadoro, D. (2007). Protein Biomarkers in Posidonia oceanica Acclimated to Low Light Regime. Ph.D. thesis, Doctorate Research Program in Plant Biology, University of Calabria XX Cycle, Italy.

Finiguerra, A., Spadafora, A., Filadoro, D., and Mazzuca, S. (2010). Surfaceactivated chemical ionization timeof-flight mass spectrometry and labeling-free approach: two powerful tools for the analysis of complex plant functional proteome profiles. Rapid Commun. Mass Spectrom. 24, 1155-1160.

Franssen, S. U., Gu, J., Bergmann, N., Winters, G., Klostermeier, U. C., Rosenstiel, P., et al. (2011). Transcriptomic resilience to global warming in the seagrass Zostera marina, a marine foundation species. Proc. Natl. Acad. Sci. U.S.A. 108, 19276-19281.

Gobert, S., Defawe, O., Lepoint, G., Demoulin, V., and Bouquegneau, J. M. (2001). Anthesis effects on Posidonia oceanica (L.) Delile phenology. Hydrobiologia 455, 121-125.

Gobert, S., Cambridge, M. L., Velimirov, B., Pergent, G., Lepoint, G., Bouquegneau, J. M., et al. (2006). "Biology of Posidonia," in Seagrasses: Biology, Ecology and Conservation, eds A. W. D. Larkum, R. J. Orth, and C. M. Duarte (Berlin: Springer Verlag), 387-408.

Gobert, S., Laumont, N., and Bouquegneau, J. M. (2002). Posidonia oceanica meadow: a low nutrient high chlorophyll (LNHC) system? BMC Ecol. 2:9. doi:10.1186/1472-67852-9

Gobert, S., Lejeune, P., Chery, A., Boissery, P., Sartoretto, S., Andral, B., et al. (2012). "Assessment of the ecological status of Posidonia oceanica meadow with a "Non Destructive Shoot Method": NDSM," in Proceedings of the Mediterranean Seagrass Workshop Essaouira, Morocco.

Gobert, S., Sartoretto, S., RicoRaimondino, V., Andral, A., Chery, B., Lejeune, P., et al. (2009). Assessment of the ecological status of Mediterranean French coastal waters as required by the water framework directive using the Posidonia oceanica rapid easy index: PREI. Mar. Pollut. Bull. 58, 727-733.

Gobert, S. M., Kyramarios, G., Lepoint, C., Pergent-Martini, G., and Bouquegneau, J. M. (2003a). Variations at different spatial scales of Posidonia oceanica (L.) Delile beds; effects on the physico-chemical parameters of the sediment. Oceanol. Acta 26, 199-207.

Gobert, S. O., Defawe, G., Lepoint, V., Demoulin, V., and Bouquegneau, J. M. (2003b). Anthesis effects on Posidonia oceanica (L.) Delile phenology. Hydrobiologia 455, 121-125.

Gu, J., Weber, K., Klemp, E., Winters, G., Franssen, S. U., Wienpahl, I., et al. (2012). Identifying core features of adaptive metabolic mechanisms for chronic heat stress attenuation contributing to systems robustness. Integr. Biol. (Camb.) 4, 480-493.

Hall-Spencer, J. M., Rodolfo-Metalpa, R., Martin, S., Ransome, E., Fine, M., Turner, S. M., et al. (2008). Volcanic carbon dioxide vents show ecosystem effects of ocean acidification. Nature 454, 96-99.

Heber, U., Bligny, R., Streb, P., and Douce, R. (1995). Photorespiration is essential for the protection of the photosynthetic apparatus of C3 plants against photoinactivation under sunlight. Bot. Acta. 109, 307-315.

Hemminga, M. A., and Duarte, C. M. (2000). Seagrass Ecology. Cambridge: Cambridge University Press.

Hermand, J. P. (2003). "Acoustic remote sensing of photosynthetic activity," in Seagrass Beds, Scaling Methods in Aquatic Ecology. Measurement, Analysis, Simulation, eds L. Seuront and P. G. Strutton (Boca Raton, FL: CRC Press LLC), 65-96.

Hermand, J.-P., and Alberotanza, L. (2000). "A novel acoustic tomography experiment in the lagoon of Venice," in La Ricerca Scientifica per Venezia. Il Progetto Sistema Lagunare Veneziano. Modellistica del Sistema Lagunare. Studio di Impatto Ambientale, vol. II, part 1.4 (Padova :
Atti dell' Istituto Veneto di Science, Lettere ed Arti), 199-222.

Invers, O., Romero, J., and Pérez, M. (1997). Effects of $\mathrm{pH}$ on seagrass photosynthesis: a laboratory and field assessment. Aquat. Bot. 59, 185-194.

Jiang, C. Z., and Rodermel, S. R. (1995). Regulation of photosynthesis during leaf development in RbcS antisense DNA mutants of tobacco. Plant Physiol. 107, 215-224.

Kraemer, G. P., Mazzella, L., and Alberte, R. S. (1997). Nitrogen assimilation and partitioning in the Mediterranean seagrass Posidonia oceanica. Mar. Ecol. 18, 175-188.

Lepoint, G., Havelange, S., Gobert, S., and Bouquegneau, J. M. (1999). Fauna v.s. flora contribution to the leaf epiphytes biomass in a Posidonia oceanica seagrass bed (Revellata Bay, Corsica). Hydrobiologia 394, 63-67.

Lepoint, G., Jacquemart, J., Bouquegneau, J. M., Demoulin, V., and Gobert, S. (2007). Field measurments of inorganic nitrogen uptake by different epifloral components colonising the seagrass Posidonia oceanica (Monocotyledon, Posidoniaceae). J. Phycol. 43, 208-218.

Lepoint, G., Millet, S., Dauby, P., Gobert, S. J. M., and Bouquegneau, J. M. (2002). An annual nitrogen budget of the seagrass Posidonia oceanica as determined by in situ uptake experiments. J. Sea Res. 48, 173-179.

Lipkin, Y., Beer, S., Best, E. P. H., Karesalo, T., and Salonen, K. (1986). Primary production of macrophytes. Terminology, approaches and a comparison of methods. Aquat. Bot. 26, 129-142.

Macreadie, P. I., Hindell, J. S., Keough, M. J., Jenkins, G. P., and Connolly, R. M. (2010). Resource distribution influences positive edge effects in a seagrass fish. Ecology 91, 2013-2021.

Massa, A. N., Childs, K. L., Lin, H., Bryan, G. J., Giuliano, G., and Buell, C. R. (2011). The transcriptome of the reference potato genome Solanum tuberosum Group Phureja Clone DM13 516R44. PLoS ONE 6:e26801. doi:10.1371/journal.pone.0026801

Mazzuca, S., Filadoro, D., Vannini, C., Marsoni, M., Cozza, R., Bracale, M., et al. (2009). Seagrass light acclimation: 2-DE protein analysis in Posidonia leaves grown in chronic low light conditions. J. Exp. Mar. Biol. Ecol. 374, 113-122.

Medwin, H., and Clay, C. S. (1998). Fundamentals of Acoustical Oceanography. Boston: Academic Press.
Migliaccio, M., De Martino, F., Silvestre, F., and Procaccini, G. (2005). Meadow-scale genetic structure in Posidonia oceanica L. (Delile). Mar. Ecol. Prog. Ser. 304, 55-65.

Modigh, M., Lorenti, M., and Mazzella, L. (1998). Carbon assimilation in Posidonia oceanica: 714 biotic determinants. Bot. Mar. 41, 249-256.

Odum, H. T. (1956). Primary production in flowing waters. Limnol. Oceanogr. 1, 102-117.

Oetjen, K., Ferber, S., Dankert, I., and Resuch, T. B. H. (2010). New evidence for habitat-specific selection in Wadden Sea Zostera marina populations revealed by genome scanning using SNP and microsatellite markers. Mar. Biol. 157, 81-89.

Oetjen, K., and Reusch, T. B. H. (2007). Genome scans detect consistent divergent selection among subtidal vs. intertidal populations of the marine angiosperm Zostera marina. Mol. Ecol. 16, 5156-5157.

Pasqualini, V., Pergent-Martini, C., Clabaut, P., and Pergent, G. (1998). Mapping of Posidonia oceanica using aerial photographs and side-scan sonar: application of the islands of Corsica (France). Estuar. Coast. Shelf Sci. 47, 359-367.

Pergent, G., Bazairi, H., Bianchi, C. N., Boudouresque, C. F., Buia, M. C., Clabaut, P., et al. (2012). Mediterranean Seagrass Meadows: Resilience and Contribution to Climate Change Mitigation, A Short Summary/Les herbiers de Magnoliophytes marines de Méditerranée: Résilience et Contribution à L'atténuation des Changements Climatiques, Résumé. Gland, Switzerland and Málaga. Spain: IUCN.

Pfaffl, M. W., Horgan, G. W., and Dempfle, L. (2002). Relative expression software tool (REST) for groupwise comparison and statistical analysis of relative expression results in real-time PCR. Nucleic Acids Res. 30:e36. doi:10.1093/nar/30.9.e36

Platt, T., Gallegos, C. L., and Harrison, W. G. (1980). Photoinhibition of photosynthesis in natural assemblages of marine phytoplankton. J. Mar. Res. 38, 687-701.

Procaccini, G., Beer, S., Björk, M., Olsen, J., Mazzuca, S., and Santos, R. (2012). Seagrass ecophysiology meets ecological genomics: are we ready? Mar. Ecol. 33, 522-527.

Procaccini, G., Dattolo, E., Innocenti, A. M., Mazzuca, S., Cavallini Natali, A. L., Gu, J., et al. (2010). Differential gene expression profiling under different light conditions in Posidonia 
oceanica (L.) Delile by SSH analysis. Rapp. Comm. Int. Mer Médit. 39, 641-642.

Procaccini, G., Olsen, J. L., and Reusch, T. B. H. (2007). Contribution of genetics and genomics to seagrass biology and conservation. J. Exp. Mar. Biol. Ecol. 350, 234-259.

Quick, W. P., Schurr, U., Fichtner, K., Schulze, E. D., Rodermel, S. R., Bogorad, L., et al. (1991). The impact of decreased Rubisco on photosynthesis, growth, allocation and storage in tobacco plants which have been transformed with antisense rbcS. Plant J. 1, 51-58.

Reusch, T. B. H., Veron, A., and Preuss, C., Weiner, J., Wissler, L., Beck, A., et al. (2008). Comparative analysis of expressed sequence Tag (EST) libraries in the seagrass Zostera marina subjected to temperature stress. Mar. Biotechnol. (N.Y.) 10, 297-309.

Reusch, T. B. H., and Wood, T. E. (2007). Molecular ecology of global change. Mol. Ecol. 16, 3973-3992.

Ruggiero, M. V., Turk, R., and Procaccini, G. (2002). Genetic identity and homozygosity of North Adriatic populations in Posidonia oceanica: an ancient post-glacial clone? Conserv. Genet. 3, 71-74.

Runcie, J. W., Paulo, D., Santos, R., Sharon, Y., Beer, S., and Silva, J. (2009). Photosynthetic responses of Halophila stipulacea to a light gradient: I - in situ energy partitioning of non-photochemical quenching. Aquat. Biol. 7, 143-152.

Runcie, J. W., and Riddle, M. J. (2012). Estimating primary productivity of marine macroalgae in East Antarctica using in situ fluorometry. Eur. J. Phycol. 47, 449-460.

Ruocco, M., Brunet, C., Lorenti, M., Lauritano, C., D’Esposito, D.,
Riccio, M., et al. (2012). Posidonia oceanica photoadaptation to the depth gradient. Biol. Mar. Med. 19, 63-64.

Schulze, W. X., and Usadel, B. (2010). Quantitation in mass-spectrometrybased proteomics. Annu. Rev. Plant Biol. 61, 491-516.

Serra, I. A., Innocenti, A. M., Di Maida, G., Calvo, S., Migliaccio, M., Zambianchi, E., et al. (2010). Genetic structure in the Mediterranean seagrass Posidonia oceanica: disentangling past vicariance events from contemporary patterns of gene flow. Mol. Ecol. 19, 557-568.

Serra, I. A., Lauritano, C., Dattolo, E., Puoti, A., Nicastro, S., Innocenti, A. M., et al. (2012). Reference genes assessment for the seagrass Posidonia oceanica in different salinity, $\mathrm{pH}$ and light conditions. Mar. Biol. 159, 1269-1282.

Serra, I. A., and Mazzuca, S. (2011). "Posidonia oceanica: from ecological status to genetic and proteomic resources", in Seagrass: Ecology, Uses and Threats, ed. R. S. Pirog (New York: Nova Science Publishers), 71-116.

Spadafora, A., Filadoro, D., Mazzuca, S., Bracale, M., Marsoni, M., Cardilio, M., et al. (2008). 2-DE polypeptide mapping of Posidonia oceanica leaves, a molecular tool for marine environment studies. Plant Biosyst. 142, 213-218.

The Royal Society. (2005). Ocean Acidification due to Increasing Atmospheric Carbon Dioxide. Policy Document 12/05. London: The Royal Society.

Tomasello, A., Di Maida, G., Calvo, S., Pirrotta, M., Borra, M., and Procaccini, G. (2009). Seagrass meadows at the extreme of environmental tolerance: the case of $P$. oceanica in a semi-enclosed coastal lagoon. Mar. Ecol. 30, 288-300.

Van der Ben, D. (1971). Les epiphytes des feuilles de P. oceanica (L.) Delile sur les côtes françaises de la Méditerranée. Mem. Inst. R. Sci. Nat. Belg. 168, 1-101.

Vogel, C., and Marcotte, E. M. (2012). Insights into the regulation of protein abundance from proteomic and transcriptomic analyses. Nat. Rev. Genet. 13, 227-232.

Webb, W. L., Newron, M., and Starr, D. (1974). Carbon dioxide exchange of Alnus rubra: a mathematical model. Oecologia 17, 281-291.

Wilson, C. J., Wilson, P. S., Greene, C. A., and Dunton, K. H. (2012). Seagrass meadows provide an acoustic refuge for estuarine fish. Mar. Biol. 159, 2311-2322.

Wilson, O. B. (1988). An Introduction to the Theory and Design of Underwater Transducers. Los Altos, CA: Peninsula Publishing.

Winters, G., Nelle, P., Fricke, B., Rauch, G., and Reusch, T. B. H. (2011). Effects of a simulated heat wave on photophysiology and gene expression of high- and low-latitude populations of Zostera marina. Marine Ecology Progress Series 435, 83-95.

Wissler, L., Codoñer, F. M., Reusch, T. B. H., Olsen, J. L., Procaccini, G., and Bornberg-Bauer, E. (2011). Back to the Sea twice: identifying candidate plant genes for molecular evolution to marine life. BMC Evol. Biol. 11:8. doi:10.1186/1471-214811-8

Wissler, L., Dattolo, E., Moore, A. D., Olsen, J. L., Migliaccio, M. Bornberg-Bauer, E., et al. (2009). Dr. Zompo: an online data repository for Zostera marina and Posidonia oceanica ESTs. Database doi:10.1093/database/bap009
Zhang, W. B., and Wang, L. (2009). Label-free quantitative proteome analysis of skeletal tissues under mechanical load. J. Cell. Biochem. $108,600-611$.

Conflict of Interest Statement: The authors declare that the research was conducted in the absence of any commercial or financial relationships that could be construed as a potential conflict of interest.

Received: 31 January 2013; accepted: 12 February 2013; published online: 19 March 2013.

Citation: Mazzuca S, Björk M, Beer S, Felisberto $P$, Gobert S, Procaccini G, Runcie J, Silva J, Borges AV, Brunet $C$, Buapet $P$, Champenois W, Costa MM, D'Esposito D, Gullström M, Lejeune $P$, Lepoint $G$, Olivé I, Rasmusson LM, Richir J, Ruocco M, Serra IA Spadafora A and Santos R (2013) Establishing research strategies, methodologies and technologies to link genomics and proteomics to seagrass productivity, community metabolism, and ecosystem carbon fluxes. Front. Plant Sci. 4:38. doi: 10.3389/fpls.2013.00038

This article was submitted to Frontiers in Plant Proteomics, a specialty of Frontiers in Plant Science.

Copyright (C) 2013 Mazzuca, Björk, Beer, Felisberto, Gobert, Procaccini, Runcie, Silva, Borges, Brunet, Buapet, Champenois, Costa, D'Esposito, Gullström, Lejeune, Lepoint, Olivé, Rasmusson, Richir, Ruocco, Serra, Spadafora and Santos. This is an open-access article distributed under the terms of the Creative Commons Attribution License, which permits use, distribution and reproduction in other forums, provided the original authors and source are credited and subject to any copyright notices concerning any third-party graphics etc. 